
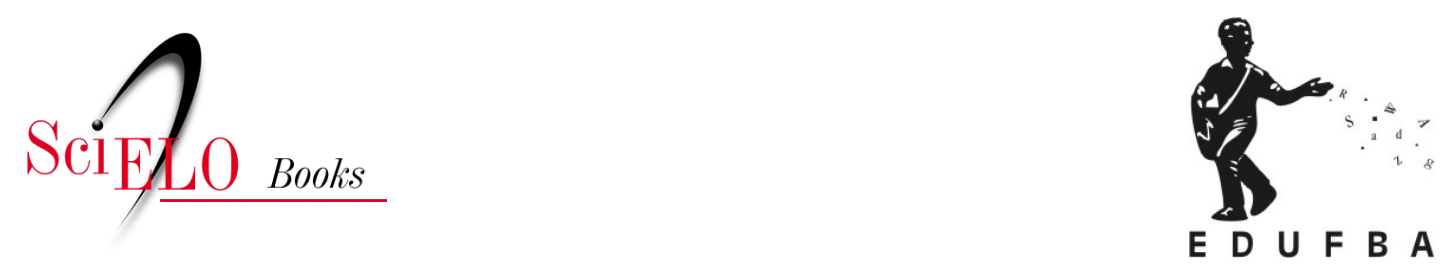

\title{
Rodrigues Dória: a chama da proibição da maconha no Brasil
}

\author{
Luísa Saad
}

\section{SciELO Books / SciELO Livros / SciELO Libros}

SAAD, L. Rodrigues Dória: a chama da proibição da maconha no Brasil. In: "Fumo de negro": a criminalização da maconha no pós-abolição [online]. Salvador:

EDUFBA, 2019, pp. 25-67. Drogas: clínica e cultura collection. ISBN: 978-65-5630297-3. https://doi.org/10.7476/9786556302973.0004.

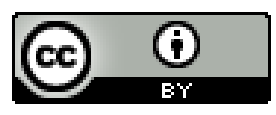

All the contents of this work, except where otherwise noted, is licensed under a $\underline{\text { Creative }}$ Commons Attribution 4.0 International license.

Todo o conteúdo deste trabalho, exceto quando houver ressalva, é publicado sob a licença Creative Commons Atribição 4.0.

Todo el contenido de esta obra, excepto donde se indique lo contrario, está bajo licencia de la licencia Creative Commons Reconocimento 4.0. 


\section{ROORIGUES DÓRIA: A CHAMA DA PROIBIÇÃO DA MACONHA NO BRASIL}

Em 27 de dezembro de 1915, José Rodrigues da Costa Dória representou o estado da Bahia, a Faculdade de Direito, o Instituto Geográfico e Histórico e a Sociedade de Medicina Legal e Criminologia da Bahia no $2^{\circ}$ Congresso Científico Pan-Americano, realizado em Washington (EUA). Sua comunicação, intitulada "Os fumadores de maconha: efeitos e males do vício", é conhecida como a primeira análise brasileira sobre a maconha e se tornou referência para todos os estudos seguintes sobre o tema. O texto sobre a maconha inaugurou uma série de trabalhos que se voltariam a alertar as autoridades e a população civil sobre os riscos que a planta comercializada e usada livremente poderia representar. Neste trabalho, Dória poderia aparecer apenas enquanto o pioneiro nas pesquisas sobre maconha, mas um estudo mais atento sobre sua trajetória acabou por revelar traços marcantes da sua atuação enquanto político, médico e professor. Inserido em meios que inspiravam respeitabilidade para a sociedade da época, Rodrigues Dória pôde se comunicar com figuras importantes do país e do exterior e dedicou-se a temas mais variados possiveis. Este estudo está longe de ser uma biografia que contemple a vida pessoal e toda a vida profissional de Dória. Antes disso, o que se propõe é discutir alguns dos principais elementos de sua produção acadêmica - em especial médica - e atuação política que ajudarão a compreender melhor o pensamento e os valores dessa figura fundamental na proibição da maconha no Brasil.

Ao entrar no território do sujeito, reduz-se a escala de observação para ampliar as condições de análise. Um destino individual pode confirmar o contexto em que está inserido como pode revelar as contradições que ficam ocultas sem o uso de um microscópio. Ao localizar o sujeito em vários contextos e, assim, "reconstituir o vivido", é possivel perceber 
"Fumo de Negro"

melhor o "embaralhamento das lógicas sociais". ${ }^{20}$ No caso de Rodrigues Dória, um homem letrado, de boas relações e costumes "civilizados", o método de microanálise reforça o império da realidade social da época: o prestígio que o médico tinha, a influência de seu discurso político, o status de um cidadão respeitado, sua preocupação com os rumos da nação e a importância de ocupar lugares de destaque na sociedade. Ele não era o que se chama de "homem comum". Ao contrário, representa, em muitos aspectos, o pensamento comum de uma elite nada conformada com o seu presente e muito ambiciosa sobre os rumos da nação.

\section{Formação e vida política}

Nascido em Propriá, interior de Sergipe, em 25 de junho de 1859, José Rodrigues da Costa Dória era filho do advogado Gustavo Rodrigues da Costa Dória e da dona de casa Maria da Soledade da Costa Dória. Viveu uma infância "de menino do interior" na vila de Propriá e, aos dez anos, fez seus primeiros estudos sob a vista do pai, que lhe ensinava Português, Francês e Latim. Em Aracaju estudou no Atheneu Sergipense e, bom aluno, chegou a ensinar Inglês e Matemática para os colegas mais jovens. A partir de 1876 Rodrigues Dória dedicou-se aos estudos superiores e matriculou-se na Faculdade de Medicina da Bahia no ano seguinte. Estudante dedicado, logo passou a ter aulas práticas no Hospital de Caridade mantido pela Santa Casa, quando procurou uma "república" para morar com outros estudantes. ${ }^{21}$ Em 1882, Dória diplomou-se em Medicina, defendendo a tese "Das febres paludosas complicadas do elemento typhico". Hábil nas palavras e frequentemente um exaltador de sua (falsa) modéstia, Dória faz questão de alertar os examinadores que aquele "humilde trabalho" certamente estaria "saturado de erros de sciencia e de linguagem, apezar dos esforços" empregados. ${ }^{22}$ Em 16 de dezembro de 1882 Dória defendeu sua tese e recebeu o título de Doutor em Medicina, tendo "sido approvado com distinção". ${ }^{23}$

20 Jacques Revel, "Microanálise e construção do social”, in: Jogos de escalas: a experiência da microanálise. Rio de Janeiro, Fundação Getúlio Vargas, 1998, pp. 15-38.

21 Alexandre Passos, "O centenário do professor Rodrigues Dória", Revista do Instituto Histórico e Geográfico de Sergipe, n. 23, v. XXIII, (1959), p. 77-78.

22 José Rodrigues da Costa Dória, "Das febres paludosas complicadas do elemento typhico", Tese de Doutorado, Salvador, FAMED/UFBa, 1882.

23 Registro de diplomas 1880-1886, Arquivo da Faculdade de Medicina da Bahia, p. 139. 
Para ganhar dinheiro na clinica, Dória voltou a seu estado natal e escolheu a importante cidade de Laranjeiras para trabalhar. Graças a uma reforma no ensino médico, novas cadeiras foram criadas na Faculdade de Medicina da Bahia e os professores substitutos transformaram-se em adjuntos. Incentivado, Rodrigues Dória voltou à Bahia, após dois anos, para concorrer à cadeira de Medicina Legal. Foi classificado em primeiro lugar e recebeu a nomeação oficial em 5 de dezembro de 1884 , no Rio de Janeiro, das mãos do Imperador Pedro II. ${ }^{24}$ Concorreu à cadeira de Patologia Médica, em 1888, e foi classificado, mas não assumiu o posto. Em setembro de 1892 tomou posse da cátedra, da qual era substituto: a de Botânica e Zoologia. Em função da Reforma Benjamin Constant, que assegurou a posse dos substitutos previamente aprovados, a vaga de professor de Medicina Legal foi ocupada por Virgílio Damásio e depois por Nina Rodrigues - eleito substituto em 1891 e professor catedrático a partir de $1895 .{ }^{25} \mathrm{~A}$ perda da vaga de catedrático de Medicina Legal - sua grande paixão - parece ter desanimado o professor, que "não se entusiasmou por uma cátedra para a qual não fizera concurso". ${ }^{26}$ Mesmo não ocupando a cadeira, Dória ainda teria sua vida entrelaçada com a Medicina Legal, a disciplina que mais aproximava seus conhecimentos médicos e jurídicos e que parecia ser a única a dar conta dos aspectos mais obscuros da criminalidade e, principalmente, dos criminosos.

Com a fundação da Faculdade de Direito da Bahia, em março de 1891, Dória, um dos responsáveis pela instalação da nova instituição, foi ali nomeado catedrático de Medicina Legal e, posteriormente, de Medicina Pública. A incorporação do ensino de medicina legal nas faculdades de Direito seria mais um passo para a legitimação científica do campo jurídico, adotando a concepção do crime como natural. ${ }^{27}$ A inauguração da Faculdade Livre de Direito trazia para a Bahia um

24 J Pires Wynne, "Um capítulo da história política e administrativa de Sergipe: Rodrigues Dória 1908-1911". Revista do Instituto Histórico e Geográfico de Sergipe, n. 23, v. XXIII, (1959), p. 181.

25 Apesar de ser classificado em primeiro lugar, Dória não assumiu a cadeira de Medicina Legal em função da Reforma Benjamin Constant, que determinou que os classificados como substitutos anteriormente deveriam assumir, então como adjuntos. Foi o caso de Virgílio Damásio e, posteriormente, de Nina Rodrigues. A cronologia de ocupação das cadeiras pode ser vista em Eduardo de Sá Oliveira, Memória histórica da Faculdade de Medicina da Bahia - concernente ao ano de 1942 -, Salvador, Centro Editorial e Didático da UFBa, 1992.

27 Luis Ferla, Feios, sujos e malvados sob medida: a utopia médica do biodeterminismo, São Paulo, Alameda, 2009, p. 97. 
"Fumo de Negro"

movimento já em curso em outros estados: a necessidade de se criar uma inteligência local para enfrentar os problemas da nação, não apenas com novas leis, mas com uma nova consciência para um país realmente independente. No final do século XIX, em torno de uma extensa produção sobre Antropologia Criminal e Direito Penal, abundaram os debates sobre os rumos da nação. A partir do início do século XX os estudos de Medicina Legal cresceriam consideravelmente e emergiria, assim, a análise da figura do criminoso e de suas características físicas e antropológicas. ${ }^{28} \mathrm{O}$ cenário era um tanto quanto propício para receber as ideias do médico-legista Rodrigues Dória.

Segundo um discípulo da Faculdade de Direito, Dória era um "homem modesto e avêsso as luzes da publicidade, de vida sóbria, fazendo da cátedra um sacerdócio, [...] despretensioso e sério no seu labor e no seu ensinamento". O autor teceu uma série de elogios ao mestre que, com tantas virtudes de homem da ciência, comunicava-se "através de uma linguagem amena, simples, sem preocupações de estilo". ${ }^{29}$ A admiração do seguidor é louvável, mas os textos de Dória são, na sua maioria, dotados de uma linguagem rebuscada e estilizada, para muitos uma referência de autoridade intelectual naquele momento. A capacidade de Dória de articular sua escrita com a citação de autores que embasavam suas opiniões é surpreendente, fazendo com que o leitor realmente se alinhasse às suas ideias, embora o médico deixasse muitas citações em outros idiomas sem tradução, talvez uma forma de convencer o leitor da importância do tema, ao mesmo tempo em que estabelecia sua superioridade para os que não compreendiam outras línguas.

A atuação de Dória como médico, professor na Faculdade de Medicina e professor de Medicina Legal na Faculdade de Direito comumente se confunde com sua trajetória política, uma vez que parte de seus textos tiveram influência significativa, de forma direta ou indireta, na legislação brasileira. A associação entre a Medicina e o Direito proporcionava aos homens da época uma mescla de conhecimentos que se complementavam e ajudavam a colocar, sob forma de lei, o que o médico elaborasse como diagnóstico. ${ }^{30}$ Dória parecia ser o homem certo no momento certo: possuía o conhecimento médico e legal e estava inserido na cena política, precisamente na transição dos séculos, o cenário ideal para suas ideias. Menos pela mudança cronológica dos anos e mais pelo

28 Schwarcz, O espetáculo das raças, pp. 141-166.

29 Wynne, "Um capítulo da história política e administrativa de Sergipe", p. 184.

30 Schwarcz, O espetáculo das raças, p. 190. 
contexto político que aquele momento representava, o fato é que o terreno estava preparado para receber as proposições de um homem que pensava como ele.

Ao que tudo indica, a atuação política de Rodrigues Dória teve início com o convite de seus amigos Severino Vieira ${ }^{31}$ e Luís Tarquínio $^{32}$ para compor uma chapa de conselheiros municipais em Salvador. Segundo a Lei Estadual $n^{\circ}$ 4, art. 36, de 20 de outubro de 1891, os membros do Conselho Municipal poderiam agir por meio de leis, posturas, regulamentos e instruções sobre qualquer assunto ligado à administração, à economia e à política municipal. Quase todas as cadeiras eram ocupadas por membros das elites baianas. ${ }^{33}$ Dória aceitou o convite e foi eleito, servindo de 1896 a $1899 .{ }^{34}$ Nesse mesmo período, mais precisamente em 1897, foi eleito deputado federal por Sergipe pelo Partido Republicano Conservador. Reelegeu-se em 1900, 1903 e 1906 e só renunciou em 1908 para assumir a presidência de Sergipe, cargo que ocupou até $1911 .^{35}$

Durante seu primeiro mandato como deputado federal por Sergipe, Dória atuou como defensor ferrenho de melhorias na saúde pública do seu estado e, além de batalhar em defesa do Hospital Santa Isabel, o único até então, dedicou-se à construção de um novo hospital, contribuindo com recursos do próprio bolso. Segundo Dória, a saúde e a medicina em Sergipe eram "sabidamente dificeis, precárias, dramáti-

31 Severino Vieira foi Deputado Federal pela Bahia (1891-1894), Senador da República (1895-1896 / 1897-1898 / 1906-1908 / 1909-1911) e Presidente da Bahia (19001904). Ocupou o cargo de Ministro da Indústria, Viação e Obras Públicas e também atuou como Promotor Público e Juiz Municipal. Inicialmente era ligado ao Partido Conservador, o mesmo de Dória. Disponível em: <https://cpdoc.fgv.br/sites/ default/files/verbetes/primeira-republica/VIEIRA,\%20Severino.pdf>. Acesso em: 15 set. 2018.

32 Luís Tarquínio foi um empresário baiano conhecido por ser neto de escravos e filho de uma liberta e que conquistou alta posição no setor industrial, tornando-se homem rico e um dos maiores acionistas da maior indústria têxtil do Norte-Nordeste. Foi o idealizador de uma Vila Operária, em 1892, ação propagandeada por ele mesmo como empreendimento de cunho social mas também dotada de funções disciplinares e higienizadoras. Ocupou postos de destaque no cenário político e social da Bahia: foi intendente, conselheiro municipal e diretor da Associação Comercial. Ver mais em Maricélia Oliveira Santos, "Construção e desdobramentos das memórias das ações de Luiz Tarquínio", Anais Eletrônicos do VI Encontro Estadual de História, Bahia, 2008.

33 Aldrin A. S. Castellucci, "Política e cidadania operária em Salvador (1890-1919)", Revista de História, n. 162, (2010), pp. 214-219.

34 Passos, "O centenário do professor Rodrigues Dória”, p. 79.

35 Israel Beloch e Alzira Alves de Abreu (coord.), Dicionário histórico-biográfico brasileiro: 1930-1983, v. 2, Rio de Janeiro, Ed. Forense Universitária: FGV/CPDOC, 1984, p. 1112 . 
"Fumo de Negro"

cas. O Estado é rico, mas o povo é pobre. Pobre, de modo especial, de emprego, conforto e justiça. E de hospital. A população tem dificuldade para cuidar das suas doenças, apela para a flora, cada casa faz seu chá, cada cozinha inventa uma 'mesinha', cada sergipano, bom brasileiro, vira médico". A luta pela construção de mais um hospital era fundamental, uma vez que em Aracaju "reinavam o curandeirismo e as benzedeiras". ${ }^{36}$ O posicionamento de Dória - médico e político - reflete uma questão latente naquele tempo: o exercício ilegal da medicina. Com a consolidação da disciplina enquanto saber legitimado para cuidar da saúde e das doenças, qualquer prática que saísse da esfera médica oficialmente aceita não era vista com bons olhos. O decreto $n^{\circ} 169$ de 1890 já determinava, em seu Capítulo VI, quem seriam os responsáveis pelo exercício da medicina e da farmácia: apenas os graduados pelas faculdades de Medicina oficialmente reconhecidas. Vale lembrar que as práticas de curandeirismo e o ofício das benzedeiras eram, em grande parte, exercidos por negros e mestiços. O questionamento de Dória manifesta um traço antiafricanista do médico.

"Fui apresentado candidato ao alto cargo de presidente do Estado, sem pretenção absolutamente da minha parte”. Quando soube que o partido the indicava como candidato a substituto de Guilherme de Campos nas eleições de 1908, Dória escusou-se, mas as pressões de amigos políticos para aceitar o convite foram significativas. O fato é que, em 24 de outubro de 1908, Dória assumiu o cargo de presidente de Sergipe por indicação do partido situacionista, "conservando todos nos postos que occupavam, requerendo apenas que auxiliassem na difficil missão, cumprindo cada um o seu dever, sem exigencias descabidas, concorrendo cada qual para melhorar as condições do Estado". Dória se queixa de ter encontrado as "finanças avariadas", sempre buscando "normalisar e regularisar seus diversos serviços, alguns dos quaes se achavam em verdadeira confusão". ${ }^{37}$ Em determinadas passagens, Dória sugere indícios de corrupção na política local e conluios contra o seu mandato.

Torna-se compreensivel a longa explicação - que preencheu sete páginas da Revista do Brasil em 1910 - sobre sua forma de governar, "sem consultar conselheiros, muitas vezes parciaes e interessados". Talvez os "interessados" e seus interesses representassem os "vícios" que não "coadunavam" com o temperamento de Dória. Segundo o presiden-

36 Luis Carlos Facó, Sergipanos ilustres na Bahia, Salvador, Editora NSV, 1998, pp. 25-26.

37 Revista do Brasil, n. 9 e 10 (nov. 1910), pp. 1-7. 
te, "foi assim que, ao redor do juiz seccional, Dr. Francisco Carneiro Nobre de Lacerda, [...] dissimuladamente se ia formando um grupo de resistencia" ao seu governo. Embora lhe chegassem notícias sobre a intenção desse grupo, Dória não tinha receio e tampouco acreditava nos boatos, visto que o Dr. Manoel Baptista Itajahy, vice de Dória, atestava a "segura, inabalavel e irreductivel solidariedade" do juiz. ${ }^{38}$ Buscando colocar em ordem principalmente a situação financeira da administração sergipana, Dória - "não sem grande contrariedade" - foi obrigado a determinar a suspensão de todos os pagamentos. Acometido por uma moléstia - "oriunda em grande parte da sobrecarga de trabalho a que fui forçado a me entregar" - embarcou em viagem a fim de se tratar, quando um conluio se desenvolveu. Contra sua vontade, Dória "renunciou" mas logo teve seu cargo "devolvido". ${ }^{39}$

A Revista do Brasil de novembro de 1910, que noticia o episódio, é só elogios ao presidente Dória, de "espirito esclarecido, lhano, prudente, cheio de acertadas iniciativas, ponderado e cortez por excellencia, intransigente tanto quanto possivel, sem offensa aos principios e regras do bem publico", responsável por "honrado governo" e por frear

actos reprovados, sediciosos, dos adversarios que tentaram por todos os meios, os mais indignos, os mais vis, vinculados de traição, arrancar de s. exa. o governo de seu Estado, o qual tem prestado com civismo, energia, intelligencia e honestidade, serviços de alto relevo. ${ }^{40}$

Os elogios excessivos a Dória e a sua inteligência, esforço, amor, dedicação, confiança e progresso, entre outros atributos, sugerem uma parceria com os responsáveis pela revista, mas não foi encontrada nenhuma informação que atestasse qualquer proximidade entre o presi-

38 Revista do Brasil, p. 7.

39 Sobre a ocasião de sua renúncia, Dória explicou "a fraude tentada pelos que se diziam os meus mais dedicados amigos". Em julho de 1909, em viagem à Bahia para tratar uma doença, Dória soube que a eleição senatorial, da qual sairia vitorioso seu antecessor Guilherme de Campos, seria anulada e o mesmo não poderia concorrer a novo pleito logo em seguida. Assim, em conversa com seu vice-presidente Manoel Baptista Itajahy e com o juiz Francisco Carneiro Nobre de Lacerda, ambos o indicaram como o melhor candidato. Da Bahia, Dória enviou sua renúncia, da qual se apoderou Itajahy "por meios indignos". O presidente da República interveio na eleição senatorial em favor de Guilherme de Campos e Dória permaneceu "tranquilo", pensando que a renúncia não teria mais validade. Para sua surpresa, seu pedido de renúncia foi tornado púbico quando já não era sua vontade e o presidente teve que pedir intervenção para garantir sua volta ao governo e continuar sua história política, "tão cheia de coisas tinhosas". 
"Fumo de Negro"

dente de Sergipe e o diretor-proprietário da Revista do Brasil, José Alves Requião. A revista publicou um dossiê do governo de Dória em cujas reportagens "se refletem nitidamente os elevados intuitos patrioticos e o zelo" do presidente do estado vizinho. Na capa da revista, uma foto dele (ver Figura 2) - com dois de seus irmãos - os então farmacêuticos Pedro e Gustavo, evidenciando uma educação doméstica voltada para a área da Saúde - dá um tom familiar à publicação.

Figura 2 - Os filhos de Dona Maria da Soledad

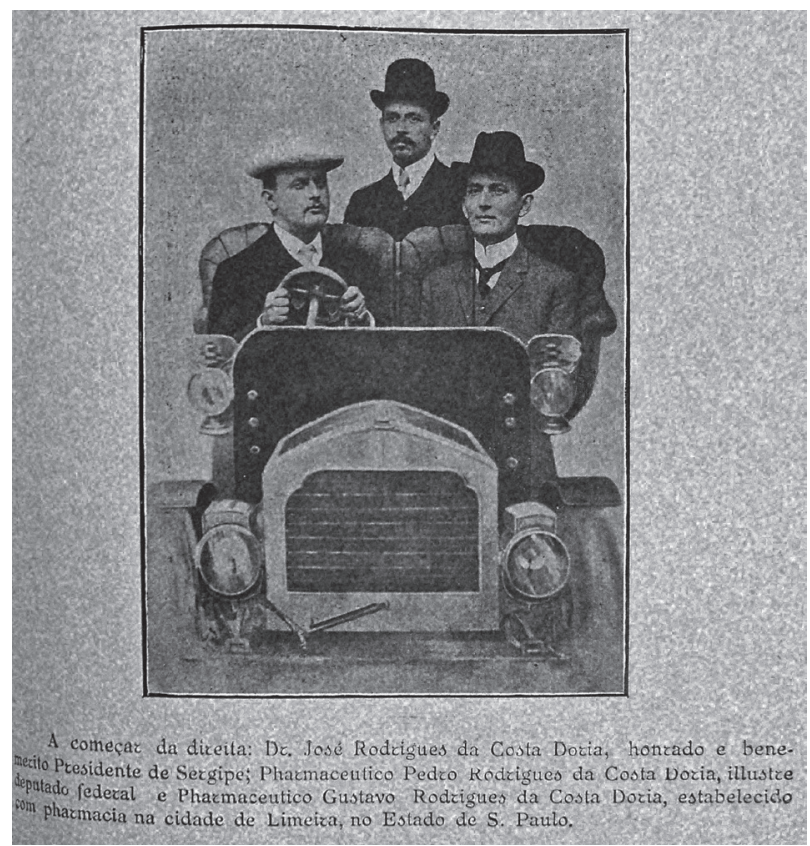

Fonte: Revista do Brasil, Salvador, n. 9 e 10, novembro de 1910, capa.

Dória gaba-se da ordem pública praticamente inalterada, em parte pela "indole ordeira da população", em parte devido à "moderação e á prudencia com que o governo procura desenvolver sua acção”. Em 1909, a instalação do serviço de identificação por datiloscopia nas cadeias do Estado havia sido uma inovação proposta pelo governo de Dória, assim como a matrícula dos carregadores, regulamentando um serviço fundamental naquele período que, diga-se de passagem, era ocupado essencialmente por negros. Ambas as ações visavam uma melhoria na salubridade do estado, que nesse item se encontraria "satisfatorio" naquele momento: controle da variola trazida de outros estados, aterramento de áreas de proliferação de mosquitos e construção de um "desinfectorio" 
para onde eram encaminhadas pessoas e bagagens vindas de portos suspeitos. No quartel de polícia Dória providenciou melhoras para "garantia do asseio e da hygiene": ladrilhou salas que acumulavam poeira nos tijolos, instalou latrinas novas, construiu camas nos dormitórios e cuidou da pintura geral do quartel. ${ }^{41}$ A higiene era, sabidamente, um elemento decisivo na conduta profissional e na performance moral dos homens daquele periodo.

Já livre de suas obrigações como presidente de Sergipe e, provavelmente, gozando de licença das instituições nas quais ensinava, Dória embarcou para a Europa em 7 de maio de 1912. Em nota, o Diário da Bahia desejou "feliz travessia" ao "eminente amigo", que se arriscava ao "velho mundo para refazer forças e aperfeiçoar seus estudos em observações scientificas". ${ }^{42}$ Entre janeiro e novembro de 1913, Dória comandou, no Diário da Bahia, uma sessão de destaque, veiculada sempre na capa, nomeada "Cartas de Paris", na qual publicava textos sobre os mais variados assuntos. A coluna não tinha uma frequência definida, aparecendo seis, sete e até nove vezes no mesmo mês. A "carta" que inaugurou a sessão girava em torno do julgamento de uma mulher que era acusada de assassinar o próprio marido por... envenenamento! ${ }^{43}$ Venenos e crimes praticados com o seu emprego eram quase uma obsessão de Dória.

Em algumas ocasiões o correspondente apenas enviava textos traduzidos retirados de grandes jornais que circulavam na França, na Inglaterra ou em algum outro local da Europa. Frequentando reuniões importantes que discutiam temas científicos do passado e do presente, Dória fazia a vez de relator e tradutor das discussões, expondo sua opinião ou enviando textos próprios em poucas oportunidades. Ao que parece, a intenção da coluna era mostrar ao leitor do jornal brasileiro o nivel das discussões que aconteciam em uma terra a ser tomada como exemplo de civilização. Assim como no Brasil, na Europa se discutia o mal da tuberculose e as medidas necessárias para erradicação da doença. A "grande molestia" matava de "maneira espantosa por toda a superficie do globo" e o médico previa a solução: "é de se esperar que medidas de prophylaxia mais severas sejam tomadas". Assim como a sífilis, a tuberculose traria consequências "desastrosas para o organismo

41 Revista do Brasil, pp. 14-17.

42 Diário da Bahia, Salvador, 7 maio 1912, capa.

43 Diário da Bahia, 26 jan. 1913, capa. 
"Fumo de Negro"

e para a degeneração da raça". ${ }^{44}$ A tuberculose, por sua vez, era associada ao consumo excessivo de álcool e, como todos os vícios - inimigos da civilização e do progresso -, deveria ser combatida por meio da higienização de seus usuários.

O ano de 1913 parecia anunciar mudanças e descobertas científicas significativas, trazendo "soluções de um grande numero de problemas" e mostrando um Dória otimista: "Teremos no anno que começa uma epocha de esperanças para o bem estar relativo das gerações vindouras, livrando as de muitas molestias, prolongando-lhes a vida." Passado e presente eram temas de reflexão constante de Dória, talvez por se encontrar no "velho mundo" e se deparar com ideias que projetassem sua visão para o futuro. Em uma das cartas, as discussões científicas dão lugar a reflexões mais filosóficas, quando o autor questiona o que ficou de velho e o que havia de novo na vida contemporânea: "a natureza não mudou, ou não parece ter mudado muito [...]; mudaram os modos e os processos, porque tambem a vida se tornou muito diferente". Sempre atento à posição da mulher na sociedade, lembra que "a mulher de hoje disputa com o homem um grande numero de empregos e trabalhos [...] há menos sonsice". ${ }^{45}$

Em 4 de novembro de 1913, o Diário da Bahia comunicava o retorno ao Brasil do "illustre patricio e eminente sergipano" Rodrigues Dória, que por meses havia emprestado ao jornal "o brilho de sua collaboração". A contribuição de Dória foi de 43 cartas - todas publicadas na capa, com grande visibilidade e, na maior parte das vezes, bastante extensas - que comportavam os mais distintos temas. Eclético, Dória trazia informações sobre o que mais era discutido no ambiente europeu, como o combate às moscas, a evolução da arquitetura urbana e as estatísticas sobre cavalos de raça criados nos diferentes países, além de relatos sobre as "magnifficas" conferências assistidas na Sorbonne. De modo geral, Dória funcionou como um correspondente internacional encarregado de traduzir para os leitores brasileiros a atmosfera que vivenciava no Velho Mundo e o que estava em discussão nas esferas respeitadas da sociedade europeia. Sempre correto, em diversas publicações corrigia os erros de cartas anteriores e alertava: "feitas estas correcções, as outras entrego aos que tiverem a pachorra de me ler". ${ }^{46}$

44 Diário da Bahia, 12 fev. 1913, capa.

45 Diário da Bahia, 4 mar. 1913, capa.

46 Diário da Bahia, 30 jul. 1913, capa. 
Em 1915 Dória viajou para Washington para apresentar-se no Segundo Congresso Científico Pan-Americano, no qual divulgou seu estudo sobre os "fumadores" de maconha, o qual será aqui analisado em capítulo específico. A repercussão do trabalho de Dória foi grande, mas outros brasileiros também ganharam notoriedade com as comunicações ali apresentadas. A 19 de março de 1916, Dória publicou no Jornal do Comércio uma crônica com o título "O Brasil no Congresso Científico Pan-Americano". Nela, engrandece a participação dos três médicos que representaram o Brasil em terras estrangeiras, de forma a que fosse "conhecido da grande nação norte-americana o valor das investigações médicas no Brasil". Assim, "ficou-se sabendo nos Estados Unidos da América do Norte que no Brasil há homens trabalhadores e dedicados à ciência, obtendo do seu esforço brilhantes resultados". ${ }^{47}$ Se o Brasil deveria se espelhar nas nações que já se encontravam em estágio adiantado de "civilização", tão ou mais importante era que esses países reconhecessem os avanços brasileiros e legitimassem a produção científica em curso por aqui.

Em 1918 Dória foi eleito mais uma vez deputado federal por Sergipe - cargo que ocuparia até 1920 -, mesmo ano em que se tornou sócio correspondente da Academia Nacional de Medicina do Rio de Janeiro. ${ }^{48}$ Nesse retorno à Câmara Federal, Dória foi relator da Comissão de Saúde Pública e, atendendo à mensagem do então presidente Epitácio Pessoa, apresentou o projeto de criação do Ministério da Instrução e Saúde. ${ }^{49}$ Após as transformações politicas de 1930, Dória ainda elegeu-se deputado por Sergipe à Assembleia Constituinte em 1933 na Legenda Liberdade e Civismo, tendo participado da elaboração da nova Carta Constitucional de 1934 e exercendo mandato até abril de $1935 .{ }^{50}$ Ele foi um dos quatro deputados sergipanos nomeados em lista de 15 de maio de 1934. ${ }^{51} \mathrm{O}$ ambiente de mudanças politicas impunha a necessidade de uma nova constituição, elaborada de acordo com o pensamento jurídico da época e que reforçasse a oposição entre repúblicas "velha" e "nova". A nova carta abarcava tendências variadas e, por vezes, até opostas, ab-

47 Lael Vital Brazil, Vital Brazil: vida e obra 1865-1950, Niterói, Instituto Vital Brazil, 2001, pp. 18-19.

48 Facó, Sergipanos ilustres na Bahia, p. 27.

49 Wynne, "Um capítulo da história política e administrativa de Sergipe", p. 80.

50 Beloch e Abreu, Dicionário histórico-biográfico brasileiro, p. 1112.

51 Brasil, Assembleia Nacional Constituinte (1933-1934). Annaes da Assembléa Constituinte, Organizados pela Redacção dos Annaes e Documentos Parlamentares. 22 v., Rio de Janeiro, Imprensa Nacional, 1935-1937, p. xxxi. 
"Fumo de Negro"

sorvendo e rejeitando, ao mesmo tempo, ideias e ideais revolucionários. A referência à religião no seu preâmbulo - "Nós, os representantes do Povo Brasileiro, pondo a nossa confiança em Deus, reunidos em Assembléa Nacional Constituinte", a garantia teórica de liberdade dos cultos e a preocupação eugênica - "A lei regulará a apresentação pelos nubentes de prova de sanidade física e mental, tendo em atenção as condições regionais do país" - são alguns dos pontos importantes. A Constituição de 1934 foi a que durou menos tempo em vigor, sendo substituída em 1937, o que não anula sua importância enquanto termômetro dos temas aqui discutidos. ${ }^{52}$

Aos 74 anos, Dória ainda atuava como médico legista na Bahia. Em notícia do jornal A Tarde, de 16 de setembro de 1933, ele aparece em foto (ver Figura 3) que ilustrava uma história de sucessivos crimes: rapto e abuso de menor, suspeita de "aborto criminoso" e ocultação de restos mortais. Em companhia do delegado responsável pelo crime, "Rodrigues Dória foi ao local do facto para proceder a exhumação do feto. Feitas as escavações nada foi encontrado, tendo os porcos devorado". ${ }^{53}$

Figura 3 - Dória atuando como médico legista aos 74 anos

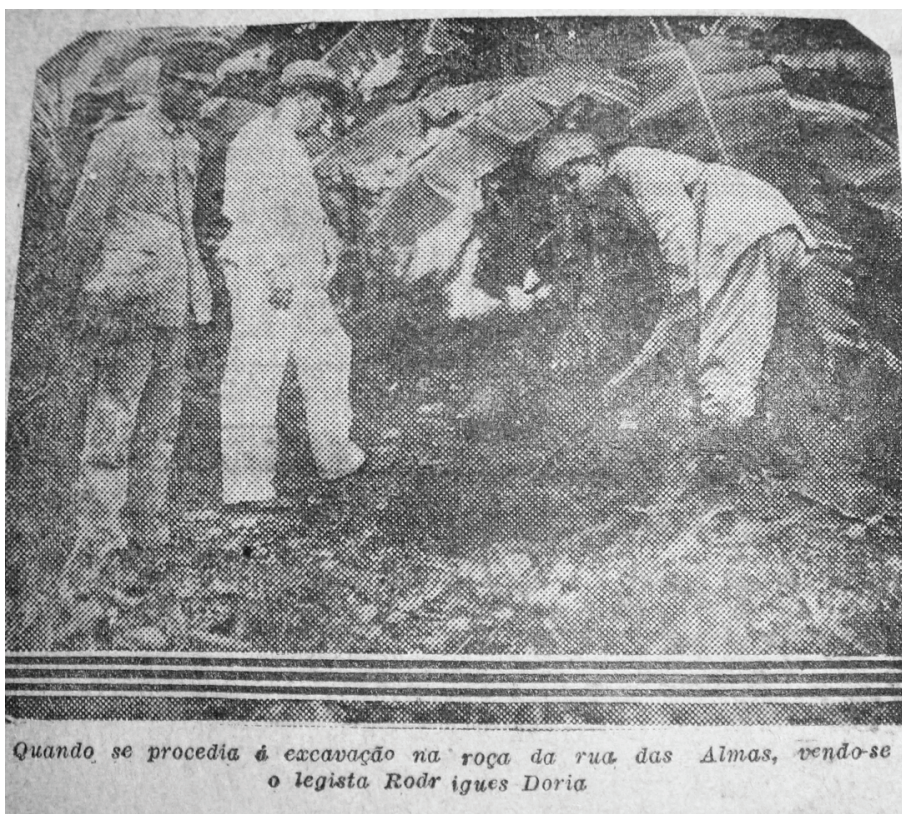

Fonte: A Tarde, Salvador, 16 de setembro de 1933, capa.

52 Ronaldo Poletti, 1934. 2. ed. Brasília, Senado Federal, Ministério da Ciência e Tecnologia e Centro de Estudos Estratégicos, 2001, pp. 16-55. (Constituições brasileiras, 3).

53 A Tarde, 16 set. 1933, Salvador, capa. 
Nesse período, ocupava o posto de professor catedrático de Medicina Legal da Faculdade de Medicina da Bahia e havia escrito diversos textos voltados à questão médico-legal em determinados aspectos, como em situações relacionadas ao casamento (1923) e em casos de epilepsia (1932). Segundo Dória, a Medicina Legal era uma "sciencia autonoma" constituída em época recente, acompanhando um "estado de civilisação adiantado, quando se apurou o respeito pela individualidade humana". Por "individualidade humana" leia-se diferenciação entre os humanos, em especial à sua raça e origem. Como uma ciência "que applica os conhecimentos medicos aos intuitos da justiça e á confecção de suas leis", a importância da Medicina Legal não precisaria ser esclarecida: "basta passar a vista nos assumptos de que ella se occupa". ${ }^{4} \mathrm{O}$ panorama esboçado em poucas páginas chama atenção pela quantidade de dados históricos de vários países, em diversos períodos, uma forma de garantir embasamento para o que o médico propunha.

Um aspecto fundamental para a boa execução das análises médico-legais era a identidade, ou identificação policial e judiciária, responsável por reconhecer "criminosos" e "vagabundos" acusados de delitos. Assim, Dória dedicou-se a relacionar os aspectos físicos fundamentais de observação no caso de identificação, como formato da cabeça, cor dos olhos, forma do cabelo, projeção do maxilar, tamanho da orelha, entre outros. Tais sinais poderiam ser decisivos na diferenciação das raças e na identificação de possiveis criminosos. ${ }^{55} \mathrm{O}$ pensamento de Dória se alinhava ao modelo de Lombroso e da Antropologia Criminal. Com o advento das grandes cidades, o criminoso poderia se ocultar no anonimato das multidões e, uma vez identificado o modelo de sujeito delinquente, mais fácil seria a sua profilaxia.

$\mathrm{O}$ auge de tais ideias no Brasil se deu quando as mesmas já estavam superadas na Europa, em fins do século XIX. A adoção brasileira desses modelos importados não foi, entretanto, acrítica. No contexto brasileiro, a ascensão de escravo a homem livre impunha um debate acerca da mestiçagem e despertava a atenção para os cruzamentos étnicos, elementos tido como fragilizadores da raça e um dos responsáveis por nosso atraso econômico, político e cultural. Apesar das análises morfológicas servirem para a identificação de qualquer "criminoso", estudos revelam certa concentração entre os "criminosos de cor", totali-

54 José Rodrigues da Costa Dória, "Definição e história da medicina legal”, Revista da Faculdade de Direito da Bahia, v. 9 (1934), pp. 119-124.

55 José Rodrigues da Costa Dória, "Identidade", Revista da Faculdade de Direito da Bahia, v. 10 (1935), pp. 75-83. 
"Fumo de Negro"

zando mais de $90 \%$ do total de craniometrias. Dória, assim como grande parte dos peritos baianos, dedicou-se a reconhecer elementos que seriam decisivos na identificação de delinquentes, criando uma espécie de "banco de dados" de formas, texturas e medidas dessas características. A especificidade da pesquisa e a criação de uma identidade de grupo profissional rendeu aos peritos baianos o reconhecimento de certa originalidade. Nina Rodrigues, discípulo de Lombroso, é identificado como o responsável pela introdução e desenvolvimento da antropologia criminal no Brasil, em especial na Faculdade de Medicina da Bahia. ${ }^{56}$

Apesar dos diversos fatores que o aproximavam de Nina, Rodrigues Dória não o cita em nenhum dos textos consultados. Segundo Mariza Corrêa, a grande preocupação de Nina era a "garantia da ordem social” e, consequentemente, a saúde pública. Controle de epidemias, prevenção e repressão ao crime, assistência aos alienados, aperfeiçoamento das leis e combate ao charlatanismo eram temas aos quais se dedicou, além de ter participação politica no meio médico e ser um dos fundadores da Sociedade de Medicina Legal da Bahia, instituição na qual Dória também teve participação. ${ }^{57}$ As semelhanças são inúmeras. A falta de referência a essa figura tão fundamental do campo médico-legal daquele período parece, no mínimo, estranha.

Uma análise mais sistemática nos permite enxergar certa tendência nas produções de Dória que, embora variasse os temas de seus estudos, mantinha o interesse em determinadas questões que são relacionadas e complementares entre si. Substâncias alteradoras da consciência, degeneração e impulsos criminais, diferenciação entre os sexos, entre outros, revelam um homem conservador preocupado com a moral, o desenvolvimento da boa raça e a manutenção da ordem. Como forma de tentar facilitar a leitura e compreensão, foram identificadas e separadas temáticas a partir das fontes deixadas pelo médico. Por vezes as categorias escolhidas para delimitar os temas se confundem ou se misturam. Em uma época em que o grau de especialização do profissional da medicina legal não era tão sofisticado, muitos profissionais da área dedicavam-se aos mais variados assuntos, utilizando-se da credibilidade de um para se arriscar no terreno do outro. Segundo Ferla, era comum que o mesmo profissional misturasse "fatos duros" - como epidemiologia - a

56 Iraneidson Santos Costa, "A Bahia já deu régua e compasso: o saber médico-legal e a questão racial na Bahia 1890-1940”, Dissertação de Mestrado, Salvador, UFBA, 1997, pp. 41-49.

57 Mariza Corrêa, "Raimundo Nina Rodrigues e a 'garantia da ordem social", Revista USP, n. 68 (dez./fev. 2005-2006), pp. 130-139. 
"fatos moles" - como o estudo da criminalidade. A mesma ciência, utilizada pelo mesmo cientista ajudava na construção de metodologias para coisificar o comportamento humano. ${ }^{58}$

\section{Os (des)caminhos para a degeneração}

Em 7 de agosto de 1897, durante seu primeiro mandato como deputado federal, Dória discursou em sessão da Câmara Federal para reiterar suas ideias diante do projeto de reforma do Código Penal. Dória iniciou suas considerações pelo título $3^{\circ}$ (Art. 24) do Código, que tratava das causas que poderiam excluir ou atenuar a responsabilidade penal, como "defeito congenito ou adquirido no cerebro". Para o médico, defeitos no cérebro não implicariam, necessariamente, em "um estado mental capaz de annular a responsabilidade, ou mesmo diminuir os elementos que se fazem precisos para regular a imputabilidade, a saber: a consciencia e a livre determinação dos actos", citando como exemplo Bicht, um famoso anatomista francês portador de um defeito no cérebro descoberto após a autópsia, mas que não impediu o desenvolvimento de faculdades que o levaram ao "territorio do genio". Segundo Dória, não deveriam ser analisados os "defeitos do cerebro", mas sim o "estado mental", que pode resultar ou não desses defeitos. Adotando como referência a classificação de moléstias mentais utilizadas por "medicos italianos", Dória defende a análise do estado das faculdades do indivíduo e não de seu cérebro: "não devemos fazer anatomia pathologica, mas artigo de lei" ${ }^{59}$ Era comum que, em análises criminais, se misturassem disciplinas voltadas para o estudo da delinquência, como Biologia, Medicina Legal, Antropologia Criminal e Psiquiatria. ${ }^{60}$ A conexão com a escola italiana remete à figura de Cesare Lombroso, médico e professor universitário considerado o fundador da Escola Positiva de Direito Penal, ou Escola italiana. Para Lombroso e seus seguidores, o delinquente era um doente, o crime era um sintoma e a pena ideal, um tratamento. Contrários à ideia do livre-arbitrio, transformavam o crime em uma expressão patológica, reservando ao condenado tratamento terapêutico no

58 Ferla, Feios, sujos e malvados sob medida, pp. 70-77.

59 José Rodrigues da Costa Dória, "Discurso", Revista da Faculdade Livre de Direito da Bahia, v. 3 (set. 1897), pp. 42-45.

60 Pierre Darmon, Médicos e assassinos na "Belle Époque": a medicalização do crime, Rio de Janeiro, Paz e Terra, 1991, p. 13. 
"Fumo de Negro"

lugar da punição. O crime representava um "evento revelador de aspectos da personalidade anormal do criminoso". ${ }^{61}$

Outra consideração levantada na discussão foi a importância do momento em que o crime fora praticado, questão já especificada nos códigos alemão e italiano, usados como exemplo por Dória. Um epilético, por exemplo, só poderia ter sua responsabilidade abolida caso cometesse o crime durante "o delírio" ou poucos instantes antes e depois dos acessos convulsivos. Outros presentes na discussão indagam como as testemunhas poderiam saber se o criminoso era "presa do acesso", ao que Dória responde que os responsáveis por isso seriam "os peritos, os médicos", que deveriam examinar o histórico do delituoso e elementos como herança, degenerescência, impulsão, forma de ataque e outros. Ou seja, ele propunha que um sujeito pudesse ser responsável em determinado momento e em outro não. ${ }^{62}$ Segundo os estudos eugenistas tão em voga naquele momento, a capacidade humana era função da hereditariedade, e não da educação. Assim, a exclusão de elementos que gerariam descendentes problemáticos, como os alcoólatras e epiléticos, era fundamental para garantir a boa linhagem do futuro, ou um "aprimoramento das populações". ${ }^{63}$ Mais uma vez emerge no discurso de Dória os ideais eugenistas de "melhoramento" da raça, a ponto de fazê-lo contradizer a si próprio, que tanto atuou em defesa da educação como caminho contrário à degeneração e à criminalidade.

Em 1910, ao falar sobre hereditariedade, genialidade e degeneração, Dória recusa-se a aceitar as ideias que colocam os gênios - "seres phenomenaes"- "na mesma ordem natural em que se acha o delinquente nato": comparar um gênio a um degenerado seria como confundir um verme com a árvore na qual ele se aloja. Assim, Dória cita Lombroso - "que acaba de ter no $6^{\circ}$ Congresso Internacional de Anthropologia Criminal, reunido em Turim, as mais justas e merecidas homenagens prestadas a seu possante talento" - e seu intuito de provar a degenerescência dos gênios e o parentesco com a loucura e o crime. Reconhece Lombroso que a natureza humana se rebela contra o conceito que procura deprimir a genialidade até o nível da idiotia: os grandes pensadores que se julgam merecedores da seleta fileira repugnam tal, assim como ele próprio. Dificil aceitar a possibilidade de que o alto desenvolvimento "da mais preciosa das fibras - a fibra nervosa" seja a consequência de

61 Ferla, Feios, sujos e malvados sob medida, pp. 23-26.

62 Dória, “Discurso", pp. 45-46.

63 Schwarcz, O espetáculo das raças, p. 60. 
um recuo, e não de um desenvolvimento, que os aproxima "dos seus antepassados remotos, os selvagens". ${ }^{64}$ Para um homem de conhecimento como Dória não seria fácil aceitar que a genialidade pudesse ter relação intima com a degeneração.

Rodrigues Dória reconhece a importância da "escola classica de criminologia" italiana, mas não se convence que essa nova doutrina fosse "um edificio acabado e prompto". Em oposição ao apontado pelo mestre Lombroso, Dória prefere pensar esses seres humanos geniais não como "o producto da degeneração, mas a consequencia do desenvolvimento anormalmente grande de uma area circumscripta do cerebro". Se os gênios, os criminosos e os loucos se aproximam em algum sentido, é na "anormalidade", no que os distancia do homem médio ou "normal". Como o criminoso, o gênio por vezes mostra-se egoísta e antissocial e com uma vaidade acima do comum. Entretanto, para Dória, "esses senões [...] não os irmaniza ao genio, representando uns e outros afastamentos do typo médio do homem, mas em sentido opposto, ou divergente". A imaginação, por exemplo, tão vigorosa nos cérebros geniais, seria um dos elementos que os afastaria dos loucos, desprovidos dessa faculdade que tem levado inúmeros gênios a descobertas e invenções de importância desmedida para a humanidade. ${ }^{65}$ Dória acaba por ignorar os tantos casos na história de grandes homens portadores de transtornos mentais tidos como gênios, como foi o caso de Vincent Van Gogh, Edgar Allan Poe, Pablo Picasso e outros.

Depois de dedicar algumas páginas à genialidade, suas origens e implicações, o médico avisa: "meu intento não é dissertar sobre o genio, pois não me sinto com capacidade e preparo para essa magna tarefa, e podem ser ellas erroneas". Entretanto, Dória garante: “a característica essencial das organizações superiores de que me venho occupando é a innovação, a creação, a potencia intellectual fóra do commum [...] de modo a avançarem muitos annos adiante das gerações suas contemporaneas". Como exemplo, "um dos maiores genios que tem possuido a humanidade", William Shakespeare, objeto de um artigo norte-americano que o apresenta como um grande estudante de Teologia, Matemática, Astronomia, Legislação, Literatura e Medicina. Parafraseando o autor do artigo em questão, Dória aponta que a produção de Shakespeare pa-

64 José Rodrigues da Costa Dória, "Genio e degeneração”, Revista da Faculdade Livre de Direito da Bahia, v. 4 (1910), pp. 49-52. 
"Fumo de Negro"

recia ter sido escrita "por um scientista do vigesimo seculo". ${ }^{66} \mathrm{O}$ curioso é que ele mesmo, Rodrigues Dória, transitava entre o Direito, a política e a Medicina, produzindo textos sobre venenos, identidade, prostituição, febres e muitos outros temas. Seria esse um indício de genialidade com o qual ele se identificava?

Dória parece também se assemelhar a Shakespeare pela atenção que ambos davam às noções de veneno e remédio, "podendo a mesma substancia ser uma e outra cousa", citando uma passagem de Romeu e Julieta: "Nas petalas desta florsinha residem o veneno e o poder de curar". A conclusão de Dória sobre genialidade e degeneração era simples: "Não são biologicamente identicos o genio, o criminoso e o louco", mas o talento e a perversidade poderiam coexistir em um mesmo indivíduo, embora sem relações obrigatórias. O fato era que o gênio representava "a mais elevada expressão do desenvolvimento [...] das faculdades intellectuaes do homem", o que lhes dava "a vantagem de se anteciparem a seus contemporâneos". ${ }^{67}$ Disfarçadamente, Dória parece se colocar no lugar do homem que se antecipa ao seu tempo.

Desde a Proclamação da República, os governantes de Sergipe já esboçavam melhorias na instrução e um dos grandes feitos do mandato de Rodrigues Dória foi a reforma da educação pública de Sergipe, através da reestruturação da Escola Normal e da implantação dos grupos escolares. Em mensagens à Assembleia Legislativa Dória manifestou sua insatisfação diante das condições materiais das escolas e falava da necessidade de uma remodelação do ensino, lamentando a situação da instrução pública no estado: "um ensino feito por methodos atrazados, e ministrados por docentes muitas vezes catados entre os protegidos e afilhados, sem se attedender ás aptidões e competencia, e só com interesse de dar emprego". ${ }^{68}$ Apesar de reclamar da falta de recursos públicos, o governo de Dória instalou os cursos de física, química, história natural e mecânica no Atheneu Sergipense, "que foram por mim mandados vir da Europa”. O ensino atrasado - "a creança aprende pela repetição fastidiosa e cançativa, e não porque se procure desenvolver nella a comprehen-

66 José Rodrigues da Costa Dória, "Genio e degeneração", Revista da Faculdade Livre de Direito da Bahia, v. 4 (1910), pp. 56-58.

67 Dória, “Genio e degeneração”, pp. 62-66.

68 Nivalda Menezes Santos, "Professoras sergipanas celibatárias e os discursos de José Rodrigues da Costa Dória (1908 a 1911): contribuições para a história da profissão docente", Anais do IV Congresso Brasileiro de história da educação, Goiás, 2006, pp. 134-136. 
são das coisas" - e sua remodelação eram tarefas que necessitavam "tempo, perseverança, e introducção de elementos novos". ${ }^{69}$

A preocupação de Dória com a educação infantil refletia mais um ideal normatizador, uma vez que para ele era na infância que podiam se desenvolver os impulsos à criminalidade ou aflorarem os genes hereditários da degeneração. A luta do professor e presidente esteve atrelada ao combate do analfabetismo e, não obstante, eram duras suas críticas à maneira da política brasileira de lidar com a educação: "Entre nós o edificio do saber tem sido construido com mais esmero de cima para baixo; arma-se a cupula sobre columnas fracas, que por sua vez assentam em alicerce muito razo". Reconhecia sua atração de professor pela questão do ensino, lamentava a existência do alto índice de analfabetos e questionava: "Que vale uma nação cuja população não sabe conhecer os seus direitos, e por isso tambem os seus deveres?" Os resultados só poderiam ser "espiritos atrazados e broncos". Um homem educado poderia compreender a razão e revoltar-se contra injustiças, mas "o ignorante, aperreado, sempre degenera em criminoso traiçoeiro". ${ }^{70}$ Para ele e para os outros médicos deterministas, educação deficiente e criminalidade, seu grande interesse, estavam associadas.

O empenho de Dória para melhorar o ensino público estava intimamente ligado à sua ambição por uma nação civilizada, uma vez que a educação seria o único meio de vencer as doenças físicas, sociais e morais que, segundo ele, assolavam o país e ameaçavam degenerar a raça. $\mathrm{Na}$ visão de Dória, as duas principais questões para resolver "o problema do analphabetismo" - "que corróe as fontes de vida e as energias de nossa patria" - seriam "tornar real e effectivo o ensino e disseminal-o por toda a parte" e, antes disso, tratar do "mestre" - o agente da instrução - e do "discípulo" - o "material com que se vae trabalhar". Formar o professor era o primeiro passo a ser dado pelos que estavam empenhados "pelo progresso e pelo futuro da patria". Projetos verdadeiros de formação de professores eram raríssimos num país tomado pela "politicagem", desprezando investimentos na cultura e no saber para satisfazer "ambições indevidas". ${ }^{71}$ Já afastado havia alguns anos da presidência de Sergipe e do cargo de deputado federal, Dória ficava cada vez

69 Revista do Brasil, p. 17.

70 José Rodrigues da Costa Dória, “Tertúlia”, Conferência realizada em 12 de novembro de 1916, Salvador, Livraria Economica da Bahia, 1926, p. 26. Acervo do Instituto Geográfico e Histórico da Bahia.

71 Rodrigues Dória, "Conferencia", Revista do Instituto Historico e Geographico de Sergipe, ano IV, vol. IV (1919), pp. 213-250. 
"Fumo de Negro"

mais à vontade para criticar a política e os políticos. Para que o ensino fosse eficaz, era fundamental conhecer o "material que vae manipular o mestre", ou seja, a criança, assim como

nas industrias há necessidade de distinguir e separar os materiaes pelas suas qualidades, afim de poder o industrial [...] conseguir um producto regular e seguro. Se o material é de primeira qualidade ter-se-á obra fina; mas é preciso de material inferior obter productos medianos, e isto só se conseguirá pelo conhecimento exacto desse mesmo material. ${ }^{72}$

A metáfora da máquina em Dória era compatível com o projeto modernizador, para cujo êxito se deveriam seguir modelos de desenvolvimento, não havendo espaço para desvios e variações bruscas. Quando na presidência de Sergipe, Dória "encomendou" de São Paulo um famoso professor para auxiliá-lo num projeto de "remodelação" do ensino, sendo alvo de muitos críticos que não consideravam necessária a vinda de um profissional de fora. Entretanto, segundo Dória, a história mostrava que as nações que recorriam ao estudo dos "outros povos, dos costumes, dos progressos, dos adiantamentos" de outros lugares, obtinham sucesso na formação de seus indivíduos e da nacionalidade, como era o caso de Roma, do Japão e dos Estados Unidos. No Brasil, São Paulo deveria servir de exemplo aos outros estados pela forma como atuava sua polícia, por exemplo, instruída e disciplinada pelos sempre inspiradores franceses. A instrução paulista era fonte de "pessoal competente, professores capazes", e fora de São Paulo que Dória "pescou" o professor Carlos da Silveira. ${ }^{73}$ Se um analfabeto não conhecia seus direitos, não poderia cumprir seus deveres, quem dirá auxiliar no engrandecimento da sua pátria. Sendo assim, um país repleto deles estava fadado ao atraso e ao fracasso, e era desse destino que Dória deseja salvar o Brasil.

Para além da instrução escolar, devia o mestre ser responsável pela continuidade da educação familiar, auxiliando "na formação do caracter, ensinando ao discipulo o cumprimento dos proprios deveres", sempre atento aos que "querem arrastar para o máo caminho", uma vez que estatísticas apontavam para o aumento da "delinquencia infantil". Tão importante quanto o desenvolvimento do corpo e da inteligência era a formação da natureza moral das crianças, já propensas à atividade de mentir. Assim, uma condição primordial para ser um bom mestre

72 Rodrigues Dória, "Conferencia”, Revista do Instituto Historico e Geographico de Sergipe, ano IV, vol. IV (1919), pp. 224-225.

73 Dória, “Conferencia”, pp. 227-231. 
era "um gráo de alta moralidade", uma vez que "a formação das novas gerações é empreza que requer homens penetrados de ideaes nobres, nutridos de pensamentos sãos e elevados". Para ter influência sobre os alunos, o mestre deveria ser estimado, tratando os discípulos com "brandura e respeito, com affecto e dignidade, com benevolencia e justiça, com paciencia e firmeza". A "consciencia da responsabilidade" e o "culto da justiça" eram tarefas a serem aplicadas por mestres que possuíssem tais qualidades e, assim, servissem de inspiração aos meninos que agiam e aprendiam por imitação. ${ }^{74} \mathrm{~A}$ atenção voltada aos menores, manifestada por Dórias em diferentes momentos, fazia parte do vasto programa eugênico empreendido nessa época, que via na infância um lugar privilegiado para prevenção do crime e da loucura: quanto melhor moldada, mais a criança teria as condições ideais de receptividade para os bons principios. ${ }^{75}$

Segundo o médico, "o desenvolvimento da intelligencia nas crianças depende de muitas circumstancias, depende da raça, do clima, da educação, civilisação, meio, religião, etc". A preocupação de Dória com a "raça", constantemente lembrada em seus textos por um ângulo determinista, tornava-se ainda mais evidente quando a questão estava relacionada diretamente ao Brasil, impregnado pelas heranças da escravidão negra. Um país "onde a civilisação é incipiente e onde raças atrasadas se tem misturado aos melhores elementos da nacionalidade, ou as raças que nos vieram da Europa", pedia uma legislação diferente, uma vez que não se poderia exigir que crianças ou jovens tivessem o discernimento sobre as condutas morais ideais. Para ele, o Estado não deveria encaminhar essas crianças "ao tamborete dos réos", mas criar medidas preventivas contra a criminalidade que estariam além da instrução escolar. ${ }^{76}$

A ausência ou a fragilidade da célula familiar eram fatores fundamentais e preponderantes no desenvolvimento da criminalidade de uma criança ou adolescente, uma vez que a rua poderia atrair um jovem vindo de um lar infeliz. Na visão de Lombroso - e de seus seguidores -, os "germes da loucura moral e do crime" eram encontrados na primeira etapa da vida de um homem, tais como certas formas já se manifestavam no embrião. Na visão positivista, o criminoso assim agia por conse-

74 Dória, “Conferencia”, pp. 237-244.

75 Maria Helena Souza Patto, "Estado, ciência e politica na Primeira República: a desqualificação dos pobres”, Estudos Avançados, v. 13, n. 35 (1999), p. 188. 
"Fumo de Negro"

quência de predisposições de ordem biológica associadas a imposições do meio, em oposição à ideia clássica que defendia o conceito do livre arbítrio. No caso dos delinquentes menores de idade, o discurso dos positivistas ganhava mais aceitação em função da vulnerabilidade e da ausência de discernimento de uma criança. ${ }^{77}$ Para além da formação escolar, fundamental era a educação caseira e os "cuidados maternos moralisadores", muitas vezes deixados de lado por mães - tidas como responsáveis pela educação caseira - que se ocupavam em trabalhos nas fábricas. ${ }^{78} \mathrm{O}$ olhar de Dória sobre a mulher evidencia ainda mais seu ponto de vista sobre degeneração e o papel feminino na busca pela nação que idealizava.

\section{Gênero: a diferenciação entre os sexos}

"Entre os dous sexos não há superioridade, nem inferioridade, mas tambem não há igualdade. Elles teem funcções differentes e se completam na natureza". ${ }^{79}$ A face naturalista do professor fica mais evidente ao falar da mulher, quando se utiliza de seu conhecimento da Escola de Zoologia para tentar convencer os colegas deputados da não inferioridade feminina, ainda que seus argumentos por vezes mostrem o contrário. Em 1892 Rodrigues Dória havia assumido a cátedra de Botânica e Zoologia da Faculdade de Medicina da Bahia. Nesse período as ciências naturais tornaram-se cada vez mais especializadas e valorizadas: a partir do "grande modelo de análise" - a Biologia - surgem novos ramos do conhecimento e outras ciências se desmembram, como a Botânica e a Zoologia. Em fins do século XIX, quando a Antropologia ainda figurava como um ramo da Biologia, o estudo do homem se dava como o estudo da fauna e da flora, ou seja, buscava-se nos aspectos naturais dos animais e dos vegetais modelos de compreensão para o conhecimento do próprio homem. ${ }^{80}$

Esse traço naturalista se faz bastante presente nos escritos de Dória. Segundo ele, assim como na Zoologia, o gênero humano apresenta, a princípio, muita semelhança entre os sexos, a qual vai se desfazendo a partir da puberdade, quando se tornam mais evidentes as diferenças

77 Ferla, Feios, sujos e malvados sob medida, p. 265-273.

78 Dória, "Discurso", pp. 54-57.

79 Ibid., p. 61.

80 Schwarcz, O espetáculo das raças, pp. 29-30 e 92. 
entre o homem e a mulher. Tal diferença também poderia ser observada nas faculdades mentais: a mulher é sempre mais propensa ao instinto e à sensibilidade, enquanto o homem é o responsável por maior força intelectual. Antes que pudessem acusá-lo de parcial, Dória faz o seu adendo: "Comtudo, é tão nobre produzir uma obra que respire o genio quanto possuir um ventre que gerou esse genio. As funcções são perfeitamente equivalentes. O homem tem a cabeça, a mulher tem o ventre". ${ }^{81}$

A forma como Dória encarava a figura da mulher e as transformações do dito sexo "frágil" aparece várias vezes na análise do médico. Em uma das cartas enviadas ao Diário da Bahia, ele expõe sua visão sobre o voto feminino. A "questão do voto das mulheres" causava um grande reboliço em diversos países e, diante de tanto "ardor turbulento", o professor não deixaria de emitir sua opinião. Embora a mulher fosse "differente do homem na sua organização, no seu destino natural, menos intelligente, em geral, do que o seu companheiro", era ela "muito mais affectiva e sentimental do que este, mais moralizada e menos inclinada ao crime", o que poderia ter uma "influencia ordeira e salutar" sobre o Estado. Entretanto, e em face dos acontecimentos recentes de protestos fervorosos por parte das mulheres, Dória revê sua posição: "fizeram-me arrefecer na minha opinião, parecendo-me que, ou por defeito de organização e temperamento, ou por deficiencia de educação, ainda não attingiram a superioridade intellectual e moral para o exercicio das funcções politicas". ${ }^{82} \mathrm{O}$ "defeito de organização e temperamento" a que Dória se refere diz respeito à disposição biológica feminina, interpretada pelos autores da época como inferior a do homem, deixando-a mais fragilizada e suscetivel a ataques histéricos, por exemplo.

As manifestações das "militantes", ao quebrarem vidraças de "um modo selvagem e odioso", mais se aproximavam de uma pratica "animal", "anarchista e destruidora". O voto nas "mãos das suffragistas militantes" mais serviria como "armas da paixão do que para o serviço da patria”, fazendo com que Dória perdesse a simpatia por elas e concluisse parafraseando um ministro inglês: "O suffragio das mulheres é um mal para o Estado e para as proprias mulheres." 83 O voto feminino e, certamente, o poder às mulheres que ele representaria causavam imenso incômodo no conservador Rodrigues Dória: "permittir as mulheres votarem é introduzir justamente o elemento hysterico no governo dos

81 Dória, "Discurso", p. 63.

82 Diário da Bahia, 04 abr. 1913, capa.

83 Ibid., capa. 
"Fumo de Negro"

povos [...] pois que as mulheres sensatas ou simplesmente calmas não votarão". ${ }^{84}$ Mais uma vez o médico associa a figura feminina à emoção, em oposição à razão que deveria predominar nesse caso.

Um fato do governo de Dória que o fez ficar muito conhecido foi um despacho na ocasião em que uma professora grávida solicitou licença de 90 dias. Analisando o requerimento, o presidente deferiu: "Concedo a licença requerida, sem vencimento algum, visto não constituir moléstia o estado em que se acha a suplicante, e nem situação independente de sua vontade." O caso ganhou grande repercussão e adentrou o acervo das histórias anedóticas, fazendo com que o próprio Dória desse sua explicação para o despacho. Segundo o então presidente, a professora, casada e residindo em Sergipe, lecionava em escola distante da cidade e já andava descuidando-se do ensino, "colocando as obrigações conjugais acima das do magistério". ${ }^{85}$ Tal medida fez parte de um projeto maior adotado no governo de Dória: o de evitar a contratação de mulheres casadas no magistério e incentivar a prática do celibato pedagógico feminino. Essa ideia começou a ser veiculada ainda nos últimos anos do século XIX, disseminando o ideal de que o magistério deveria ser uma espécie de sacerdócio, profissão só para mulheres solteiras, em oposição ao compromisso das mulheres casadas de dedicarem-se a marido e filhos. ${ }^{86}$ Em uma dessas situações, ele foi denunciado pela professora em questão por ter cortado seu salário quando essa deu entrada ao requerimento solicitando os noventa dias de licença. Diversos jornais satirizaram a resposta do presidente, como o Diário da Manhã de 11 de março: "Que não constitua moléstia, vá. [...] é licito a s. ex., que é solteirão, ignorar este ponto." O relato prossegue dando a notícia de que o governo provisório de Portugal havia acabado de decretar a concessão da licença de três meses às professoras públicas, e indaga: "Resta saber com quem está a justiça; se com os homens serios de Portugal ou com o pandego do presidente de Sergipe”. A 19 de março, o Diário da Manhã divulga a matéria extraída do Diário de Notícias da Bahia citando o caso e o despacho "irreverente" do "sr. Rodrigues Dória, que é um impenitente celibatão". ${ }^{87}$

84 Diário da Bahia, 11 jul. 1913, capa.

85 Wynne, "Um capítulo da história política e administrativa de Sergipe”, p. 186.

86 Santos, "Professoras sergipanas celibatárias e os discursos de José Rodrigues da Costa Dória (1908 a 1911)”, pp. 2-3.

Ibid., p. 6. 
Em 1916, Dória voltou a tocar na questão em conferência realizada no Instituto Geográfico e Histórico da Bahia. Segundo ele, "jamais regulamento da instrucção publica em Sergipe se occupou da gravidez ou dos partos das professoras, nem de licenças para a respectiva diéta". Em caso de moléstia a licença e o salário estariam garantidos, já que uma doença não configuraria "facto procurado, desejado; ninguém quer ou procura ficar doente. [...] Mas a gravidez e o parto estão comprehendidos na lei? São molestias, ou são funcções proprias ao sexo?”. Dória compactua com a ideia de que a gravidez é um "estado physiologico em alta pressão", ou seja, um estado de saúde sob condições de tensão e, por isso, deve receber constante cuidado. Sendo assim, "esse estado é incompativel com os arduos misteres do professorado; durante a gravidez, o parto, o puerperio e a amamentação, a mulher deve estar afastada do ensino", concluindo que achava justificado e bem empregado o despacho que havia dado cinco anos antes. ${ }^{88}$ Como aponta seu discipulo, Dória "não aceitava a liberação total da mulher", vendo-a com "outra destinação social", amparado na fisiologia e psicologia de seu tempo. ${ }^{89}$

A visita a Washington e a Nova York, em 1915, havia mostrado que seu despacho não era absurdo, e sim uma medida adotada por nações que pareciam estar em outro patamar de desenvolvimento, "os maiores pioneiros da instrucção do pôvo", que zelavam pela "excellencia de seus methodos, valor e proficiencia dos seus pedagogos e educadores". Em conversa com um "Director de importante estabelecimento escolar" de Washington, Dória soube que não havia lei que impedisse que as professoras fossem casadas, mas nos contratos e nomeações era condição exigida que a professora fosse solteira. Já em Nova York, um regulamento estabelecia que "nenhuma mulher casada será nomeada para qualquer posto do ensino", a não ser em caso de os maridos serem portadores de moléstia física ou mental que o impedisse de garantir o sustento da família. Um relatório enviado pelo Superintendente das Escolas de Nova York se alinhava às ideias de Dória, reforçando a postura de conceder licença apenas sem vencimento para mulheres em fase de dar à luz, amamentar e criar um filho. O médico comenta: "depois disto fico perplexo, sem saber se devo envaidecer por ter dado a nórma para aquelles semi-barbaros [...] ou se me devo alegrar em não acompanhar ideias indigenas, festejando-as, lisonjeando-as". ${ }^{90}$ Fica evidente a faceta

88 Dória, "Tertúlia", pp. 6-9.

89 Wynne, "Um capítulo da história política e administrativa de Sergipe", p. 187.

90 Dória, op. cit., p. 10-12. 
"Fumo de Negro"

de um Dória que se vê além de seu tempo, que se coloca como um homem de ideias avançadas e não compreendidas pelos seus conterrâneos - "semi-barbaros" que vivem no atraso - que já são realidade em nações mais avançadas e exemplos a serem seguidos pelo país.

Quando presidente de Sergipe, Dória deixou evidente ser "partidário da professora solteira em proveito e beneficio do ensino". Entretanto, não regulamentou nem promulgou qualquer decisão a esse respeito, por julgar que "a opinião [pública] não estava preparada para isso", garantindo que seu estilo de fazer política passava longe da imposição de suas opiniões. A preocupação girava em torno da pobreza de seu estado, onde a "raça" era "prolifica" e ter filhos era o divertimento do povo. O médico ignora os aspectos culturais e sociais da população e naturaliza a reprodução da "raça", como se o ato de "ter filhos" estivesse ligado simplesmente ao lazer. Por outro lado, era comum observar uma grande quantidade de "donzellas de todas as idades, desde a jovem bella e esperançosa até a virgem de cabellos brancos”, às quais poderia ser reservado o exercício do professorado. Uma vez casadas, as moças deveriam dedicar-se - e não haveria outra opção - ao marido e ao "seu formoso filhinho", trabalho que tomaria "todos os seus minutos e segundos" por uma simples exigência da natureza, pois "mulheres que tem o coração de mãe" merecem "as maiores alegrias, o maior prazer, a mais intensa satisfação", que seria ter nos braços seu filho, "o producto de suas entranhas". ${ }^{91}$ Era como se Dória encontrasse uma distinção natural entre as mulheres que devessem se tornar mães e dedicar-se exclusivamente às suas famílias e as mulheres que enveredassem pelo caminho do magistério, como se a essas últimas faltasse algo biológico que as fizessem optar por uma profissão que não permitisse a dedicação exclusiva que a maternidade e a formação de uma família exigiam.

A discussão sobre o trabalho feminino fora do lar passou a ser bastante comum nas primeiras décadas do século XX, quando grande parte do proletariado brasileiro era composto por mulheres. O contexto trabalhista feminino não era fácil: suas tarefas eram menos especializadas e mais mal remuneradas em comparação as dos homens, a legislação trabalhista não as protegia, não havia pagamento para hora extra e era comum o abuso sexual por parte dos superiores. Para os médicos higienistas, responsáveis pelos códigos normativos da vida social, as mulheres que se dedicavam ao trabalho fora de casa tendiam a ser perdidas e degeneradas. A intenção era reservar às mulheres a esfera da 
vida privada, uma vez que o trabalho externo poderia destruir a família, tornar os laços mais frouxos e debilitar a raça nacional à medida que as crianças cresceriam mais "soltas" em função da ausência da mãe. O lar era considerado o "mundo sagrado", ao passo que o universo do trabalho era associado à perdição, como um cabaré..$^{92}$

"A consequencia natural do casamento são os filhos", prega o professor, com base no que diz a Igreja sobre o "primeiro bem do casamento", e lembrando que o Código Civil prevê como dever dos conjugues "o sustento, guarda e educação dos filhos". Como uma mulher grávida, necessitando de "cuidados especiaes, regime e hygiene especiaes", poderia manter sua rotina de professora? Além das dificuldades físicas - enjoos, peso do corpo, dores -, uma mulher em estado avançado da gravidez estaria sujeita à "irritação nervosa", impedindo "que a professora trate a criança com o carinho que abranda o caracter e educa o moral". Outras questões perturbam Dória: "pergunte-se agora a um medico parteiro, a um hygienista, ou eugenista: é conveniente á saude da mulher e á do fructo da concepção o trabalho da escola?" Como exemplo, a prática dos hebreus de preservar a saúde da mulher grávida, "afim de obter uma raça forte, resistente". Após a gestação ainda vem o parto, a necessidade do "isolamento social e marital", o tempo de amamentação constante e os "outros pequenos cuidados que nenhuma outra pessôa faz com o carinho, o zêlo e o cuidado daquella que vê na debil creaturinha o sangue de seu sangue". Em resumo, somados os tempos de "evolução da gravidez, do parto, puerperio e amamentação", não sobra tempo para a mulher retomar as funções de professora, sendo perfeitamente justificada a licença sem vencimentos. ${ }^{93}$ Para ele, a mulher deveria escolher entre as funções de mãe e de professora: "mulher muito sabida não dá para mãe de família". ${ }^{94}$ Com isso, fica evidenciado seu alinhamento com as ideias predominantes no seu tempo de que o trabalho intelectual não era para ser ocupado pela mulher. Mulher servia para ser mãe e esposa, essa sua ocupação precipua.

Para Dória, o professorado poderia ser "um campo largo para a actividade do excesso de mulheres", uma alternativa para aquelas que não querem casar-se e constituir família e uma forma de não as deixar cair no limbo da prostituição. O interesse de homens em casar-se com pro-

92 Margareth Rago, "Trabalho feminino e sexualidade", in: Mary Del Priore (org.), História das mulheres no Brasil, São Paulo, Contexto, 2006, pp. 578-606.

93 Dória, "Tertúlia", pp. 14-18.

94 Diário da Bahia, 08 out. 1913, capa. 
"Fumo de Negro"

fessoras poderia, muitas vezes, estar vinculado ao fato de que essas "tem o dote do vencimento". Caso as professoras fossem impedidas de unirem-se em matrimônio, os "vadios" desistiriam da união, "e só conquistariam as professoras quem as amasse e as quizesse por mulher, com ou sem dote". Dória reproduz na íntegra um artigo publicado na Gazeta de Notícias, jornal do Rio de Janeiro - sem data especificada -, com o título "Incompetencia de solteiro", no qual o autor critica o posicionamento do presidente de Sergipe - solteiro - que jamais poderia "saber até onde vão os direitos e os deveres de uma professora casada". Para o autor do texto, citado apenas como Antonio, o presidente havia invadido "seára alheia": "metteu o nariz onde não era chamado". Dória responde às acusações assumindo seu papel de "solteirão" aos 57 anos: ${ }^{95}$

de facto, sou de todo ignorante do que se passa nas alcôvas dos casados [...] mas penso sempre que entre os casados não há má vontade, há desejo; e nos tempos de hoje, como nos de hontem, a mulher sabe, e ouve durante o acto que um dos fins do casamento é ter filhos. [...] É possivel que se eu fosse casado (não sei se os legisladores da Capital Federal o são; devem ser) tivesse mais condescendencias e carinhos pelas mulheres gravidas. ${ }^{96}$

O artigo em questão, agressivo e repleto de zombarias, parece ter incomodado Dória que, de forma espirituosa, "agradece" o jornalista "pelo anuncio que fez em seu artigo de que o ex-presidente de Sergipe ainda é uma esperança para alguma desenganada do matrimonio" - trecho que, por sua vez, não aparece no artigo que Dória diz ter transcrito na íntegra. Bem humorado, faz sua torcida e uma previsão: "E quem sabe! Benção sem conta cáhiam sobre o jornalista, se a propaganda dér resultado. Apenas tenho a desconfiança que serei boycotado pelas professoras." 97

A preocupação de Dória com a moral e a família o levou a reflexões mais elaboradas sobre a prostituição, uma das "ameaças" para os defensores do progresso republicano: "quaes as medidas sociaes para proteger esse excesso de mulheres, muitas das quaes poderão ir ter á prostituição [...] por escassez de meios de vida?”. Já tendo tocado no tema da prostituição em outras ocasiões, Dória dedicou-se a estudar a questão mais a fundo e apresentou uma memória intitulada "Regulamentação de meretricio" no I Congresso Médico Paulista, em dezembro

95 Dória, “Tertúlia”, pp. 18-19.

96 Ibid., pp. 24-25.

97 Dória, op. cit., pp. 25-26. 
de 1916. A visita prolongada de Dória à Europa pode ter sido um dos motores que impulsionaram o médico a se envolver no debate sobre a regulamentação ou não do meretrício, uma vez que diversos países começavam a cogitar essa possibilidade e a França representava o modelo de regulamentação. O Brasil já discutia a questão desde os tempos da corte imperial, embora nunca se tivesse chegado a um consenso sobre a regulamentação do ofício. ${ }^{98}$

Apesar de posicionarem-se em lados opostos, os favoráveis à regulamentação e os contrários à inclusão do meretrício sob a proteção da lei tinham muitos ideais em comum, e o principal deles era a manutenção da moral, da família e da saúde dos "homens de bem". De um lado, uns acreditavam que a regulamentação e o controle resultante dela seriam favoráveis ao controle da sifilis e, assim, da saúde dos pais de família e de suas esposas. De outro, os opositores argumentavam que, uma vez regulamentada, a prostituição poderia transmitir a falsa sensação de segurança e, assim, disseminar doenças sexualmente transmissiveis por toda sociedade. ${ }^{99}$ Rodrigues Dória estava do lado dos homens contrários à regulamentação, por considerar "illusorias as vantagens allegadas em seu favor", dando como exemplo o caso de países que adotaram o sistema e verificaram seus inconvenientes. Entretanto, o médico reconhecia a função histórica - "a prostituição é coeva da humanidade" - que a profissão tinha para os homens, "mergulhando as suas raizes até a propria organisação do genero humano". Por outro lado, o preço a ser pago não era barato: do meretrício "resultam tantos prejuizos de ordem moral no estrago do caracter, e de natureza physica, com a propagação de molestias venereas, de tão sérias e graves consequencias para o individuo e a raça". Além da transmissão de doenças, o ambiente da prostituição trazia outros perigos: "é ainda o bordel um ninho de

98 Para aprofundamento sobre o tema, ver Margareth Rago, Os prazeres da noite, Rio de Janeiro, Paz e Terra, 1991, onde a autora faz um contraponto entre o glamour e o luxo da prostituição e sua relação próxima com o crime e a ilegalidade entre o fim do XIX até meados de 1930. Luiz Carlos Soares, em Rameiras, Ilhoas, Polacas... A prostituição no Rio de Janeiro no século XIX, São Paulo, Ática, 1992, reforça a função social das prostitutas e seu papel estabilizador, analisando o momento em que se discutia a legalização do trabalho em função das preocupações higiênicas. Nélia de Santana, "A prostituição feminina em Salvador (1900-1940)", Dissertação de Mestrado, Salvador, UFBA, 1996, trata da conduta profissional das prostitutas na capital baiana e as barreiras que encontravam diante das noções de modernidade recentemente estabelecidas.

99 Cristiana Schettini Pereira, "Lavar, passar e receber visitas: debates sobre a regulamentação da prostituição e experiências de trabalho sexual em Buenos Aires e no Rio de Janeiro no fim do século XIX”, Cadernos Pagu, n. 25 (2005), pp. 25-54. 
"Fumo de Negro"

crimes". ${ }^{100}$ Uma vez desviado do seu curso civilizatório, o homem estaria caindo na degeneração e, assim, aproximando-se da possibilidade de cometer o ato criminoso.

Para o autor, a prostituição era um "vicio" e, como tal, não poderia nem deveria "ser reconhecido como um meio de vida", assim como o jogo e a embriaguez, práticas cada vez mais punidas e perseguidas. Citando Lombroso, Dória alerta que, "salvo as degeneradas", as mulheres não procuravam espontânea e voluntariamente aquela ocupação, sendo na maioria das vezes seduzidas por uma "ilusão" que ele não especifica qual, mas que se supõe ser a de acumular fundos para uma vida mais digna. Assim, não poderiam ser elas as únicas prejudicadas pela vida que levavam, uma vez que a regulamentação previa exames constrangedores, multas, internação e muito mais. Para ele, o homem era "tão culpado, ou mais, na prostituição" e, portanto, deveria ser igualmente responsável pelos males que a prática viesse causar. A regulamentação só seria válida se se estendesse aos homens "aos quaes fossem fornecidas licenças para frequentarem os bordeis, após exame de sanidade, licenças que deviam ser recusadas aos casados e aos menores de 18 annos, e só concedidas aos solteiros e viuvos". A obrigatoriedade de exames era contestada: no caso da sífilis, por exemplo, o diagnóstico só era garantido com o exame de sangue. E como obrigar alguém a fazê-lo? Para auxiliá-lo na argumentação, Dória cita Ruy Barbosa e seu discurso em 1904 contra a vacina obrigatória, no qual o jurista defende a "impenetrabilidade" da consciência e da epiderme. Para Dória, o Estado não poderia "lançar-me a mão á golla do casaco, encadear-me os punhos, lançar-me ferros aos pés, mas introduzir-me nas veias, em nome da hygiene publica, as drógas de sua medicina". ${ }^{101}$ Alguns posicionamentos de Dória, como esse, surpreendem, uma vez que vão de encontro ao autoritarismo que o mesmo deixa transparecer em outros momentos. Decerto, a ocasião fazia sua opinião.

Longe de fazer o papel de crítico que não apresenta alternativas, Dória esboça sua opinião sobre medidas a serem tomadas para além da proibição: repressão, moderação, contenção. Já que a supressão do meretrício era impossivel, cabia ao Estado e seus dirigentes procurarem maneiras para modificar e conter os "surtos e ousadias, [...] petulancias e escandalos, [...] indecencias e affronta aos bons costumes" causados

100 José Rodrigues da Costa Dória. "Regulamentação do meretrício". Revista da Faculdade Livre de Direito da Bahia, n. 5, v. 6 (1917), pp. 97-102.

101 Ibid., pp. 104-108. 
por esse mal histórico e, pelo que parece, eterno. ${ }^{102}$ A repressão e punição eram responsabilidades a serem cumpridas pela polícia mas, como era de se esperar de Dória, um "trabalho de educação" era fundamental,

para fortificar o espirito da mulher, contra os enleios da sedução, fazendo-a conhecer, até certo ponto, as desgraças a que está sujeita a mulher perdida, e infundindo-lhe no espirito o amor ao trabalho, a indifferença pelo luxo e pela vaidade, a abstenção de certos divertimentos estimulantes, e em absoluto das bebidas alcoolicas, que são a causa frequente de concessões fataes. ${ }^{103}$

Assim também deveria ser o procedimento com os homens, "tornando-o digno, protector natural da mulher, fazendo-lhe o animo bastante forte para não se entregar ao papel desonroso e deshumano de seductor". ${ }^{104}$ Enfim, homens e mulheres deveriam ser educados para tornarem-se bons maridos e esposas e fixarem relações duradouras e estáveis, formando famílias exemplares e equilibradas. Impossivel de ser exterminada, sem resultados positivos se regulamentada e não podendo ser deixada de lado, a prostituição deveria ser reprimida oficialmente pela polícia e informalmente por todos os cidadãos que ansiavam pelo progresso da nação.

\section{Orogas (ou venenos) e sua relação com o crime}

O texto mais antigo de Dória encontrado nessa pesquisa traz o título de "Envenenamento e veneno". Escrito em 1892 e publicado na Revista da Faculdade de Direito em 1893, o artigo traz as impressões dele sobre as falhas do recente código penal brasileiro, já merecedor de uma "segunda modificação", a fim de "expurgar a nossa legislação criminal do grande numero de senões que nella se encontrão á mão de semear". Para Dória o código trazia alguns avanços em relação ao anterior, de 1830, mas pecava em muitos pontos, apesar de seguir o "excellente modelo" do código penal italiano, que trazia aspectos revelados por Lombroso e seguidos pelos discípulos brasileiros, como Nina Rodrigues. As falhas eram devidas à falta de um "exame e critica das faculdades juridicas e da magistratura do paiz", que deveriam originar um corpo de leis "tão completo e perfeito quanto possivel [...] precisando

102 Dória, "Regulamentação do meretrício", pp. 115-116.

103 Ibid., p. 117.

104 Ibid., loc. cit. 
"Fumo de Negro"

apenas de adaptação ao meio, ao clima e á raça”. ${ }^{105}$ Nas entrelinhas dos escritos de Dória, acerca dos mais variados assuntos, é onde se revela seu pensamento científico, baseado no determinismo biológico e geográfico, cada vez mais perceptíveis pelos seus posicionamentos quanto ao Brasil e seu povo.

Um dos reparos necessários ao Código Penal de 1890 seria o tratamento ao "abominavel crime de envenenamento". Embora fosse um crime "tão antigo quanto a propria humanidade" deveria ser considerado um "assassinato aggravado, como um crime revelando maior perversidade e dólo", além de implicar em "traição, cobardia, abuso de confiança n'elle envolvidos e dos seos sinistros e infernaes preparativos". Dória elogia as leis de outras nações e se refere à legislação de 1830 com saudosismo, quando a pena máxima era a de morte, mas o que interessa aqui é a discussão que o médico faz sobre o que seria um "veneno" e sua influência sobre os crimes. Contrário às definições usuais do veneno enquanto substância - em pequena dose - capaz de alterar a saúde ou destruir a vida, Dória questiona com os exemplos da própria medicina: "os toxicos mais violentos são constantemente empregados pelos medicos como preciosos medicamentos [...] e é justamente quando as pequenas doses são excedidas que estas substâncias de medicamentos se tornão venenos". Sendo assim, "a questão de pequena dose" não poderia estar ligada à definição do veneno e Dória, sabiamente, apontava que a diferença entre remédio e veneno poderia estar na dosagem. ${ }^{106}$

Utilizando-se da técnica de falar bem, Rodrigues Dória passeia por definições de autores estrangeiros e exemplos de experiências de outros médicos, como um "celebre Doutor negro" em Paris que desejava um remédio contra o cancro e, ao receitar uma pomada para uma mulher, causou seu envenenamento. ${ }^{107}$ Pobre da mulher, "que teve a infelicidade de consultar esse charlatão". A escolha de Dória pelo "docteur noir" como exemplo de charlatanismo evidencia traços do seu preconceito racial. O professor segue criticando o código e sugerindo melhores definições para o crime de envenenamento. Dória defendia penas mais duras para o crime de envenenamento - por ação "mechanica ou thermica". Seu estudo sobre venenos e o crime de envenenamento foi encaminhado ao

105 José Rodrigues da Costa Dória, "Envenenamento e veneno", Revista da Faculdade Livre de Direito da Bahia, n. 2 (nov. 1893), p. 91.

106 Dória, "Envenenamento e veneno", pp. 92-94.

107 "Le docteur noir" era assim conhecido, como consta em livro sobre ele: C. Fauvel. La vraie vérité sur M. Vriés - Le docteur noir. Paris, 1859. 
Congresso Nacional, em 1897, durante seu mandato como deputado federal por Sergipe, com a proposta de reforma do Código Penal nesse item. Para Dória, os crimes cometidos sob efeito de entorpecente deveriam ter sua pena minimizada. Alguns "estados" poderiam retirar a responsabilidade do indivíduo e não necessariamente enviá-lo a um "hospicio penal", para onde iam os loucos e epiléticos inimputáveis. O delírio febril, o sonambulismo ou a embriaguez poderiam dirimir a imputabilidade na visão de Dória. Para a recuperação dos "loucos", os hospícios eram necessários, uma vez que os mesmos "obedecem ás ordens que lhes são dadas, e temem os castigos e ameaças, que com frequencia mudam radicalmente o seu procedimento". Sendo assim, "não se póde taxar absolutamente de crueldade os castigos infligidos nos hospicios de louco, castigos que, na maior parte das vezes, são de effeito benefico na conducta e na cura do individuo". Quanto aos indivíduos que cometessem crime "fóra da orbita do seu delírio", deveriam ser punidos normalmente: "é antes um facinora do que um alienado que age". Responsabilidade penal parcial e pena proporcional deveriam ser aspectos contemplados pelo código, uma vez que um "degenerado", por exemplo, poderia ser "um louco effectivamente, mas não louco completo": "entre o estado mental perfeito e o estado de irresponsabilidade absoluta, há milhares de gráos, dependentes da indole, da determinação e da pessoa de que se trata". Assim, Dória sugere que os sujeitos que cometessem um crime com a consciência e livre determinação diminuídas, deveriam ser considerados responsáveis, sendo-lhes porém aplicada uma pena reduzida de um ou dois terços a ser cumprida em hospício penal ou casa de prisão. ${ }^{108}$ Com o advento da República, os programas higienizadores empreendidos nas grandes cidades, dotados de cunho eugênico buscavam, além de eliminar as doenças, separar a pobreza e a loucura da população saudável. ${ }^{109}$

Sobre a avaliação e punição de crimes cometidos sob estado de embriaguez, o autor considera extremamente equivocada a comparação de um crime cometido por um indivíduo que buscou a embriaguez como meio de se encorajar e um indivíduo que se embriagou acidentalmente: "são diferentes e não podem ser parificadas". Crimes cometidos por ébrios constantes que buscam a embriaguez para cometer o delito não deveriam ter atenuação de pena ou serem irresponsabilizados. No caso de perturbação mental em função do abuso de álcool, a responsabili-

108 Dória, "Discurso", pp. 47-50.

109 Schwarcz, O espetáculo das raças, p. 34. 
"Fumo de Negro"

dade seria da Psiquiatria e o indivíduo deveria ser encaminhado a um "asylo de loucos". Assim, Dória apresenta uma emenda que prevê responsabilização dos indivíduos que cometerem crimes em estado de embriaguez, seja ela para encorajá-lo ou por costume, devendo a pena ser cumprida em casas de prisão. ${ }^{110}$ Em uma das cartas enviadas de Paris, Dória transmite aos leitores brasileiros notícias sobre o último relatório da casa de saúde que tratava das "victimas do alcoolismo" na Inglaterra. Mais da metade dos casos de alcoolismo eram atribuídos à "extraordinaria sociabilidade", seguido pelo excesso de ociosidade. Embora o consumo de álcool pelos ingleses em tempos passados fosse maior, ainda eram necessárias medidas para diminuir a incidência de "borrachos". ${ }^{111}$

A polêmica em torno da responsabilidade de menores de idade revela um Dória sensibilizado com a possibilidade de uma criança delituosa ser culpabilizada e punida como um adulto, lembrando que a educação seria a melhor maneira para evitar jovens que pudessem cometer delitos. O Art. 26 do Código Criminal previa que os menores de nove anos poderiam ser responsabilizados criminalmente, proposição da qual discordava: "a minha observação não me leva a acreditar que uma criança que tenha apenas completado 9 anos possua, em regra, o discernimento, que lhe dê a responsabilidade na pratica do crime". Para defender seu ponto de vista, o médico e deputado usou como exemplo o código italiano, no qual a idade de nove anos era a estabelecida como limite da irresponsabilidade, questão polêmica no país por alguns julgarem a idade muito baixa. Assim, "si na Italia, que é um paiz muito pequeno com relação ao nosso, porém mais civilisado, a idade de 9 anos foi considerada baixa [...] que diremos nós em relação a este vasto paiz [...] no qual a civilisação tem-se limitado a uma certa faixa ao longe do mar?". ${ }^{112}$ A preocupação com a infância era uma característica herdada de Lombroso, que acreditava que nas crianças se pudesse perceber tendências que caracterizariam o criminoso, como a inclinação para a vingança, o ciúme, a mentira, a falta de senso moral e a curiosidade exacerbada, entre outras. Para os positivistas, "era na infância que o futuro se decidia". ${ }^{113}$ Portanto, Dória acreditava ser fundamental o acompanhamento dos miúdos pela família, pelo professor e pelo médico, a

110 Dória, “Discurso", pp. 52-53.

111 Diário da Bahia, Salvador, 07 jun. 1913, capa.

112 Dória, op. cit., pp. 54-57.

113 Ferla, Feios, sujos e malvados sob medida, pp. 265-291. 
fim de se reconhecer suas inclinações criminosas o mais cedo possivel e tentar corrigi-las.

Sempre atento às questões contemporâneas e interessado nas polêmicas sobre responsabilidade penal, Dória participou ativamente das discussões sobre a implantação de manicômios judiciários no Brasil. Após o Código Penal de 1890 determinar que os "criminosos loucos" deveriam ser entregues às famílias ou internados nos hospícios públicos, a depender da decisão do juiz, uma lei de 1903 definiu que cada estado deveria reunir recursos para a construção de manicômios judiciários. Nesse período foi criada, no Hospício Nacional de Alienados no Rio de Janeiro, a "Seção Lombroso", destinada a abrigar os "loucos criminosos". Todavia, o primeiro espaço exclusivamente reservado a esse fim só foi inaugurado em 1921, no Rio de Janeiro, servindo de asilo e prisão, guardando sob o mesmo teto loucos e criminosos insanos. O contexto do início do século XX e a "questão do crime" exigiam novas medidas de contenção e repressão e uma reflexão mais séria sobre as liberdades individuais resultantes do liberalismo. A necessidade de se consolidar uma nova concepção de homem e de sua relação com a sociedade - fundada em formulações positivistas e cientificistas - exigia uma nova organização para o tratamento do crime. Assim, com a fusão da Psiquiatria e da Antropologia Criminal, do saber médico e do saber legal, nasciam os manicômios judiciários. ${ }^{114} \mathrm{O}$ estudo de Dória - que já carregava consigo os saberes adquiridos com a Medicina e o Direito - "O crime - suas causas, seus atores e seu tratamento", publicado em 1925, serviu como referência a autores que se debruçaram sobre a questão e continua sendo fonte nas análises contemporâneas que questionam os manicômios como forma de recuperação do indivíduo. ${ }^{115}$

A partir da segunda década do século XX, diante dos esforços para a criação dos sanatórios, os estudos sobre toxicomania aumentaram de forma significativa e, a partir daí, foi sendo definida uma área clínica dedicada a essa questão. Os psiquiatras foram os principais responsá-

114 Sérgio Luis Carrara, "A História esquecida: os Manicômios Judiciários no Brasil", Revista de Crescimento e Desenvolvimento Humano, n. 1, v. 20 (abr. 2010).

115 Entre as obras que fazem referência ao estudo criminal de Dória, podem ser citadas: Vasco Smith de Vasconcellos, As dírimentes do Codigo Penal, São Paulo, Livraria Academica, 1923; Arthur Ramos, Loucura e crime: questões de psychiatria, medicina forense e psychologia social, Porto Algre, Livraria Globo, 1937; Antônio Moniz Sodré de Aragão, As três escolas penais: clássica, antropológica e crítica (estudo comparativo), 7a ed., Livraria Freitas Bastos, 1938; Sergio Carrara, Crime e loucura: o aparecimento do manicômio judiciário na passagem do século, Rio de Janeiro, EDUERJ; São Paulo, EDUSP, 1998. 
"Fumo de Negro"

veis pela problematização do tema das drogas nos âmbitos científico e psiquiátrico e o uso de drogas passou a ser definido como uma patologia mental que tendia a se tornar hegemônica a ponto de merecer tamanha dedicação. ${ }^{116} \mathrm{Um}$ pouco adiantado e sempre antenado às discussões contemporâneas, Dória apresenta ao $6^{\circ}$ Congresso Brasileiro de Medicina e Cirurgia, realizado em São Paulo, em 1907, seu estudo "Toxemia e crime". Seguindo a linha de sua pesquisa sobre envenenamento e intoxicação, Dória continuava a estabelecer conexões entre a ingestão de substâncias e a prática criminosa, mas nesse caso dissertou sobre a intoxicação opcional, ou a escolha pelo uso de tóxicos "como o alcool, o ether, o opio", tão ameaçadores à "ethica social, à moral e à lei”. Tais substâncias seriam responsáveis por "desarranjos profundos" no corpo humano, como a embriaguez, não relacionada apenas ao álcool - "a mais antiga e geralmente conhecida" - mas também determinada por outros agentes. Assim, o autor determina a "narcomania (mania dos narcoticos)" como sinônimo para "embriaguez", mudando a denominação a depender da substância tóxica utilizada. ${ }^{117}$

Dos "venenos sociais" descritos por Dória, o álcool seria o predominante nas causas das "doenças sociaes", visto seu histórico de "influência na abolição da consciencia e do senso moral", "conhecida de mui alta antiguidade". Embora reconheça os "valiosos serviços" que o álcool possa prestar ao homem, o médico aponta que "em muitos casos se torna senhor absoluto, exigente e severo, senão o seu mais cruel inimigo". Com a expansão da indústria e do comércio, a disseminação do álcool já permeava "todas as camadas sociaes", tornando "o alcool acessivel até a tribus não attingidas por essa mesma civilisação", ou seja, as camadas pobres. Ao Brasil restava seguir o exemplo da Inglaterra, "muito mais temperada do que foi", mostrando "que é bom ser sóbrio ou abstemio". Vicioso para os moralistas, delinquente para os juristas, motivo de zombaria aos olhos do povo, transgressor das leis divinas para os teólogos e doente na análise dos médicos, o "bebado" seria, sob qualquer aspecto, um sujeito necessitado de atenção, de impulsos moralizadores e éticos, de controle rígido e de acompanhamento psiquiátrico, uma vez que a intemperança seria uma moléstia aproximada da loucura. ${ }^{118}$ Doenças fí-

116 Julio Cesar Adiala, "Drogas, medicina e civilização na Primeira República”, Tese de Doutorado, Rio de Janeiro, Fundação Oswaldo Cruz, 2011, p. 147-149.

117 José Rodrigues da Costa Dória, Toxemia e crime: memória apresentada ao $6^{\circ}$ Congresso Brasileiro de Medicina e Cirurgia, Rio de Janeiro, Leuzinger, 1907, pp. 55-57.

118 Dória, Toxemia e crime, pp. 58-59. 
sicas, loucura, desmoralização e impulsos criminosos são aspectos que se misturam nas análises de Rodrigues Dória.

Como "o estado de alcoolismo chronico não se manifesta egualmente em todas as pessôas", Dória parte para a análise de outras influências, "tanto individuaes quanto externas, physicas e sociaes". Das "causas predisponentes mais importantes", sexo, idade, temperamento e raça seriam algumas. "Todos os temperamentos estão sujeitos á intemperança”, mas a incidência em pessoas de temperamento nervoso parecia maior. Nos negros, "mais vivazes, enthusiastas e facilmente excitaveis", a embriaguez não chegava a ser tão profunda e durava pouco a "influencia anesthesica" do álcool. Já os indígenas mostravam "notavel inclinação para a embriaguez; bebem todas as vezes que pódem, até a morte rapida e violenta". ${ }^{119}$ A fácil excitação dos negros poderia ser em função de uma propensão ao "temperamento nervoso", talvez associado a uma característica mais animal e menos racional. Julgando a fácil inclinação dos indígenas à embriaguez, Dória não deixa explícita as bases da sua conclusão. Aos brancos o médico não dedica análise claramente, mas aponta uma ordem de países - dos essencialmente "brancos" aos latinos - em escala decrescente da temperança: Alemanha, Rússia, França, Suécia, Noruega e Suiça - nações que tiveram influência dos mongóis - seguidos de Itália e Espanha, países com maior influência africana.

Um dos mais sérios males, segundo Dória, era "a transmissão da degeneração", ou seja, a herança genética, que impelia o indivíduo ao uso de bebidas alcoólicas e outros narcóticos. A ideia da degeneração estava associada à eugenia, conjunto de ideias e práticas relativas ao melhoramento ou aprimoramento da raça humana, inaugurado por Francis Galton, em 1889, na obra Natural Inheritance (Herança Natural). Desde o início do século XX surgiram, por toda a parte, "sociedades de eugenia" voltadas para o "melhoramento da raça" baseado no estudo da hereditariedade. ${ }^{120} \mathrm{O}$ movimento eugenista buscava "sanar" a sociedade de indivíduos que portassem determinadas enfermidades ou características tidas como "indesejáveis" - a exemplo de doenças mentais ou os chamados "impulsos criminosos". As ações propaladas pelos eugenistas foram as mais cruéis possiveis: desde campanhas incentivando ou proibindo determinados casamentos até a implementação de leis que se baseavam em projetos de esterilização de homens e mulheres considerados degenerados e capazes de gerar uma prole "desgraçada",

119 Dória, Toxemia e crime, pp. 62-63.

120 Darmon, Médicos e assassinos na "Belle Époque", pp. 193-199. 
"Fumo de Negro"

passando pela regulamentação da imigração, o registro do pedigree das famílias e a implantação de educação eugênica obrigatória nas escolas. ${ }^{121}$ Assim como as ervas daninhas, os maus elementos deviam ser cortados pela raiz como forma de que a "praga" não se espalhasse e contaminasse os frutos de boa constituição.

Elemento essencial na definição do vício da embriaguez, a pobreza encontrava no alcoolismo uma identificação que se transformava em um "circulo vicioso [...] contribuindo o primeiro para manter o segundo, e este para a génese do primeiro". Os trabalhadores com ocupações "que acarretam esgotamento" teriam maior propensão à ebriedade, assim como os funcionários de hotéis e tavernas. Alguns fatores cotidianos poderiam influenciar na entrega ao alcoolismo, como perturbações domésticas, comerciais e financeiras, a obsessão religiosa e mesmo desgraças inesperadas ou momentos de desespero. Moléstias cerebrais e as perturbações causadas por elas conduziriam ao vício da embriaguez, assim como a sífilis e sua influência depressiva sobre o sistema nervoso. ${ }^{122}$ Pobreza, trabalhos desgastantes e problemas financeiros são elementos decisivos destacados por Dória e não é difícil deduzir qual era a população vítima desses fatores que, segundo o médico, intensificavam o vício.

Após a excitação inicial e antes do adormecimento final, o bebedor tendia a ficar perturbado e irritado, estágio que o levaria a cometer crimes por estar "confuso o sentimento da justiça e da moralidade". Não raramente o alcoolismo levaria à loucura ou, parafraseando Aristóteles, conclui Dória que a embriaguez é a loucura voluntária, podendo levar à imbecilidade alcoólica e a impulsos suicidas e homicidas. ${ }^{123}$ Após citar diversos autores e expor os risco do consumo excessivo do álcool, Dória aponta as "evidentes relações entre o alcoolismo e o crime": diversas estatísticas provam a "frequência da intemperança nos delinquentes e criminosos", principalmente os crimes cometidos sob o impulso da emoção. A embriaguez também é apontada como causa da prostituição e a prostituição como causa da embriaguez: "o enfraquecimento da vontade e a perda do senso moral, que acarrecta a embriaguez, difficilmente permittirão manter a correcção de conducta que deve observar uma mulher honesta". ${ }^{124}$

121 Maria Eunice de S. Maciel, "A eugenia no Brasil”, Revista Anos 90, n. 11 (jul. 1999), pp. 121-130.

122 Dória, Toxemia e crime, pp. 67-68.

123 Ibid., pp. 70-73.

124 Ibid., p. 75. 
Embora a embriaguez pelo álcool fosse a mais perigosa - por sua fácil obtenção e pela disseminação do uso -, Dória reserva uma parte de seu estudo para analisar a "embriaguez" por outras substâncias, uma vez que "o habito dos narcoticos se vai alastrando, e não é sem grave consequencias e grandes damnos, acarretando não só a degenerescencia do individuo e da próle", sujeitando-o à "prática de vários actos contrarios á moral e á lei". O éter, "mais espalhado do que se pensa", era utilizado em maior escala pelas mulheres e, principalmente, pelas envolvidas com a prostituição, podendo levar à prática de "crimes leves". $\mathrm{O}$ ópio e a morfina representavam perigos maiores para a sociedade e, citando Thomas de Quincey - escritor inglês conhecido pela obra Confissões de um comedor de ópio -, Dória aponta os riscos de degradação física, mental e moral do usuário, embora lembre, contradizendo-se, que Quincey vivera até os 70 anos de idade. A cocaina - "substancia de grande valor therapeutico", assim como o ópio e a morfina - apresentaria mais riscos em função da depressão que se segue a seu uso. "A cocaina é mais mortal do que a morphina, e mata sem aviso; é mais estimulante do que o opio" e pode levar a acessos de violência furiosos e impulsos homicidas. Cloral, bromuretos, antipirina e fenacetina são outras substâncias indicadas por Dória como perturbadoras e depressoras do sistema nervoso, capazes de conduzir o usuário a impulsos criminosos e suicidas. ${ }^{125}$

Após dedicar-se à análise das substâncias e sua relação com o crime, Dória, enfim, se dispõe a orientar as medidas necessárias para o "tratamento" dessas moléstias. Um tanto realista, analisa a impossibilidade de acabar com o álcool e seu uso, sendo necessário "o esforço de cada um e o esforço de todos, dos particulares e dos governos, dos hygienistas e dos legisladores, afim de que possa o mal ser reduzido". As "tendencias hereditarias, a fraqueza originaria, a deficiencia innata de dominio moral e a susceptibilidade á influencia dos agentes narcoticos" deveriam ser 'curadas' com empenho para além da medicina: "a direcção do tratamento deve ser outra, os meios hygienicos e prophilaticos devem ser os preferidos, pois nenhuma medicina os iguala". Entre as "escolas onde se aprende a beber" estavam os clubes e os salões estes não tão "perigosos", já que frequentados por pessoas "em geral de educação elevada" - e as tavernas, "ponto de reunião de pessôas pouco educadas", onde seria uma afronta não aceitar o convite para um drink. Uma boa medida, segundo Dória, seria o aumento dos impostos sobre 
"Fumo de Negro"

as bebidas, "de modo a tornal-as objecto de luxo e de difficl acquisição", não se devendo criticar a inacessibilidade dos pobres ao álcool, "pois é entre estes, no operariado, onde se recruta principalmente o exercito dos bebedos". ${ }^{126}$ Ou seja, o médico aplica uma lógica de classe - ou de discriminação de classe - como solução, que complementa sua leitura racial do consumo de álcool.

Entretanto, a medida de "mais alto valor" era o desenvolvimento da educação, "tanto intellectual, quanto physica, das massas": "é preciso que a educação seja completa, perfeita, bem dirigida e dentro dos preceitos da moral e acompanhada de bons exemplos". Além da boa convivência e de boas referências dentro de casa, as escolas também eram responsáveis por "fornecer noções de chimica, physiologia e hygiene, que lhes permittam comprehender os males que a dróga póde causar ao organismo, incutir no seu espirito o tédio pelo detestavel vicio". Segundo Dória, "tudo o que se acaba de ser dito em relação ao alcool se applica aos narcoticos", que deveria ter a venda restrita em farmácias e sob apresentação de receita médica. Finalizando o texto, apresenta suas conclusões, entre elas a de que "a embriaguez é uma causa de primeira ordem na producção do crime", valendo-se da ressalva de que "o alcool não é em absoluto um mal; póde prestar bons serviços ao homem". Preventivos de grande valor seriam as propagandas em favor da temperança, melhoramento das condições de vida do proletariado e a educação literária, moral e física. ${ }^{127}$ Esse estudo de Dória encontrou prestígio no meio médico brasileiro. Após ser apresentado em São Paulo em 1907, foi lembrado na Gazeta Médica da Bahia, de fevereiro de 1908, como uma "excelente memória" para servir de guia na batalha contra o problema "sempre atual do alcoolismo" e outras toxemias relacionadas intimamente à prática de crimes. ${ }^{128}$

O fascínio de Dória pelos venenos e drogas, seus efeitos e aplicações era tão grande que o autor publicou uma versão ampliada do seu texto de 1893, "Envenenamento e veneno". O texto revisto é dedicado aos alunos do quinto ano da Faculdade de Direito de 1914, com o título inverso: "Veneno e envenenamento". A versão inicial havia sido publicada na Revista da Faculdade de Direito, na Gazeta Médica da Bahia e transcrita no Diário Oficial de 17 de janeiro de 1893. De fato, no início do texto, pouco há de diferente entre as duas versões. Muitos trechos

126 Dória, Toxemia e crime, pp. 83-87.

127 Ibid., pp. 87-88.

128 Gazeta Médica da Bahia, n. 8, vol. XXXIX (fev. 1908), pp. 377-380. 
são praticamente transcritos, o autor passeia por inúmeras definições de envenenamento e o "caso do Doutor Negro" [grifo do autor] continua sendo o melhor exemplo de charlatanismo médico. A novidade aparece a partir da segunda parte do texto, inexistente na primeira versão. Dória esboça uma tentativa de classificação dos venenos, explorando uma vasta bibliografia que se propôs a essa análise e que "não é perfeita", por dar maior atenção à origem do veneno do que à ação causada ou o contrário: "Nenhuma classificação, pois, concilia as exigencias da Historia Natural e da Physiologia". Nem mesmo Dória consegue estabelecer qual critério deveria ser adotado para tal classificação e, assim, resolve adotar o modelo proposto por Gaister, curiosamente a única classificação citada que dispensou atenção aos "Narcoticos inebriantes": "Alcool, Ether, Cannabis indica". ${ }^{129}$

O efeito e a ação dos venenos também são analisados nessa segunda versão, podendo ser local ou remota, como no caso do álcool e do ópio, que produziam "a principio delirio, e depois somno e coma". $\mathrm{O}$ autor discorre sobre a influência da dosagem, de combinações químicas e do método de administração como modificadores da atividade das substâncias tóxicas associadas às diversas condições individuais. ${ }^{130}$ A dedicação de Dória a aprofundar-se no assunto é visivel: diversos autores são citados, mitologias analisadas, obras literárias visitadas. Os casos mais famosos de envenenamento são descritos e os menos famosos também. Entretanto, justamente por essa dedicação e aprofundamento, surge a pergunta: por que um médico esclarecido e estudioso como Dória coloca praticamente no mesmo patamar substâncias como a estricnina, o arsênico, o álcool, a maconha e o éter? Segundo o médico, "o alcool, o ether, o canhamo, depois de grande excitação do cerebro, causam profunda fraqueza muscular, nauseas, vomitos, visão dupla, falta de coordenação dos movimentos, coma, e morte". ${ }^{131}$ Substâncias de origens diferentes e com composições e efeitos diversos deveriam ser estudadas de forma individual, segundo a própria análise de Dória. O álcool, como se sabe, se consumido em excesso, pode conduzir ao coma. A maconha, por sua vez, conduz o indivíduo a, no máximo, um sono profundo. Quais eram os interesses de Dória ao colocar os

129 José Rodrigues da Costa Dória, Veneno e envenenamento: lições proferidas na Cadeira de Medicina Pública da Faculdade de Direito, Salvador, Officinas do Diário da Bahia, 1914, pp. 17-18.

130 Ibid., pp. 18-27.

131 Ibid., p. 28. 
"Fumo de Negro"

"venenos" - leia-se drogas - sob uma mesma definição e relacionar todos ao crime de envenenamento?

Neste sentido, é também curioso o posicionamento de Dória, em 1907, sobre a proibição: "é problemático o resultado de se querer suprimir a embriaguez pela prohibição. Esse methodo faz apenas com que o bebedor occulte o seu vicio", citando, em seguida, o "fracasso" da "lei seca" nos Estados Unidos, e concluindo que "não se pode prohibir o commercio do alcool ou de bebidas fermentadas, mas póde-se impedir de ser ébrio nas ruas". ${ }^{132}$ Essas colocações chamam atenção pois vão de encontro à opinião de Dória, expressa em seu célebre texto de 1915, na maneira de lidar com a maconha: "A proibição do comércio da planta, preparada para ser fumada, poderá restringir a sua disseminação progressiva.". ${ }^{133} \mathrm{O}$ que faria a proibição da maconha ser eficiente e a do álcool não? Ou melhor: quem eram os usuários de maconha que deveriam ser criminalizados?

Da vida pessoal de Dória, pouco se tem conhecimento. As fontes que fazem menção à sua família de origem apontam para um afeto respeitoso e de agradecimento para com os pais. Pelo menos dois dos irmãos de Dória levaram vida semelhante: Pedro graduou-se em Farmácia na Faculdade de Medicina da Bahia, mas atuava no Direito e exerceu o cargo de juiz em São Paulo, onde foi presidente da Sociedade de Higiene. Também foi deputado federal por Sergipe no mesmo período em que Dória atuou como presidente do estado. João formou-se médico também na faculdade de Salvador, atuou como médico analista do Serviço de Medicina Legal do Estado da Bahia e serviu interinamente no lugar de preparador de Medicina Legal na Faculdade de Medicina. ${ }^{134}$ Sendo homens nascidos no interior de Sergipe na segunda metade do século XIX, os filhos do Dr. Gustavo Dória provavelmente foram educados com o ideal de traçarem seus destinos profissionais na tão estimada Faculdade do Terreiro de Jesus - a primeira do Brasil -, em uma Bahia já adiantada em relação a Sergipe. Em tempos de valorização da medicina os irmãos da família Dória escolheram o caminho da ciência como forma de ganhar a vida e, consequentemente, prestígio social.

Não se tem notícia de que nosso personagem tivesse casado e constituído família. As notícias do período em que fez o célebre despa-

132 Dória. Toxemia e crime, pp. 84-85.

133 Dória, "Os fumadores de maconha", p. 12.

134 Armindo Guaraná, Dicionário Biobibliográfico Sergipano, Rio de Janeiro, Editora Pongetti, 1925, p. 274 e 458-459. 
cho ao pedido da gestante indicam que Dória era solteiro, ou melhor, "solteirão", deixando um rastro de deboche sobre o estado civil do então presidente. Dificil entender como um homem tão apegado aos preceitos da família, da moral e dos bons costumes, crítico do aborto e do meretrício, preocupado com os jovens de bem e o destino da nação, tenha chegado ao fim da vida sem constituir uma família. Talvez Dória tivesse optado por dedicar seu tempo exclusivamente às ocupações que escolheu, às quais se engajava com convicção e entrega. O fato é que a pesquisa mostra que Dória não deixou herdeiros que pudessem, mais tarde, contar aspectos mais intimos desse homem que foi, segundo um admirador, "um capitulo da História de Sergipe".

Dória faleceu em Salvador no ano de 1938, cidade que escolheu para dividir sua atenção com a terra natal. Inserido em um contexto que nos explica muito de sua personalidade, escolhas e posicionamentos, Rodrigues Dória buscou - e conseguiu - visibilidade nos setores de maior destaque social. Como professor, nas faculdades de Medicina e Direito, conquistou muitos alunos e discípulos. Entretanto, não foram encontradas muitas pistas a respeito de interlocutores dentre colegas de ensino e academia. De certa forma, Dória parece um tanto quanto isolado nas faculdades em que conquistou considerável espaço e reconhecimento pelo corpo discente.

Enquanto deputado encaminhou projetos que julgava de suma importância ao país. Ao mesmo tempo em que se arriscava a opinar sobre o futuro e a modernidade, Dória mantinha as raízes conservadoras do passado, "sentindo a cada passo a influência de velhos hábitos do seu século, mais conservador que rebelde" ${ }^{135}$ Escreveu muitos outros textos nas temáticas mais variadas, os quais não foram contemplados aqui; alguns não puderam ser localizados, outros foram deixados de fora por serem julgados menos importantes para a discussão. O certo é que José Rodrigues da Costa Dória conquistou reconhecimento e teve parte de suas ideias levadas à prática. Seu texto sobre maconha é referência constante tanto para autores que concordam com a proibição e repressão ao seu consumo quanto para os que criticam o modelo proibicionista e os desdobramentos sociais consequentes dele.

135 Wynne, “Um capitulo da história política e administrativa de Sergipe”, pp. 185-191. 